\title{
Spatio-Temporal Variation and Controlling Factors of Water Quality in Yongding River Replenished by Reclaimed Water in Beijing, North China
}

\author{
Yilei Yu ${ }^{1,2, \dagger}$, Muyuan Ma ${ }^{1,2, \dagger}$, Fandong Zheng ${ }^{3, *}$, Licai Liu ${ }^{3}$, Nana Zhao ${ }^{1,2}$, Xiaoxia Li ${ }^{1,2}$, \\ Yongmin Yang ${ }^{4}$ and Jia Guo ${ }^{1,2, *}$ \\ 1 Institute of Wetland Research, Chinese Academy of Forestry, Beijing 100091, China; \\ yuyilei1222@126.com (Y.Y.); xiaogu67@sina.com (M.M.); annazhao2009@163.com (N.Z.); \\ kindxiaoxia@163.com (X.L.) \\ 2 Beijing Key Laboratory of Wetland Services and Restoration, Beijing 100091, China \\ 3 Beijing Water Science and Technology Institute, Beijing 100048, China; 1lc1021@126.com \\ 4 Research Center on Flood and Drought Disaster Reduction of the Ministry of Water Resources, \\ China Institute of Water Resources and Hydropower Research, Beijing 100038, China; yangym@iwhr.com \\ * Correspondence: zfd@bwsti.com (F.Z.); gjiaty@163.com (J.G.) \\ $\dagger$ These authors contributed equally to this work.
}

Received: 20 March 2017; Accepted: 19 June 2017; Published: 23 June 2017

\begin{abstract}
Reclaimed water is useful for replenishing dried up rivers in North China, although changes in water quality could be an issue. Therefore, it is essential to understand the spatio-temporal variation and the controlling factors of water quality. Samples of Yongding River water were collected seasonally, and 24 water quality parameters were analyzed in 2015. All waters were alkaline, and nitrate-nitrogen was the main form of nitrogen, while phosphorus was mostly below detection level. The water quality parameters varied in time and space. Cluster analysis showed a distinct difference between winter and the other seasons and between the natural river section and the section with reclaimed water. Based on the analysis of Gibbs plots, principal component analysis, and ionic relationships, the water chemistry was controlled by dissolution of rocks in natural river section, the quality of replenished water, the effects of dilution, and the reaction of aqueous chemistry in the reclaimed water section. The positive oxidation environment in most of the river water was conducive to the formation of nitrate-nitrogen by nitrification, and not conducive to denitrification.
\end{abstract}

Keywords: water quality; reclaimed water; controlling factors; Yongding River

\section{Introduction}

North China is an important area of political, economic, and cultural development, while it has been facing serious water shortages. Under the influence of continual droughts, rapid socio-economic development, and a large consumption of water resources, surface runoff is significantly reduced, leading to a large number of dry rivers [1,2]. Beijing, the capital of China, has been confronted with severe water scarcity for the last 30 years. The annual average rainfall of Beijing is $584.7 \mathrm{~mm}$, which is mainly concentrated from June to September [3]. The city's total water consumption was 3.82 billion $\mathrm{m}^{3}$ in 2015, while the surface water resources were 932 million $\mathrm{m}^{3}$, and the gap was filled by excess use of groundwater [2]. Although the south-to-north Water Diversion (1 billion $\mathrm{m}^{3} /$ year) largely alleviated water scarcity, water demand was not fully met. Yongding River, one of the seven major river systems in the Haihe River Basin, flows through Inner Mongolia, Shanxi, and Hebei provinces, Beijing, Tianjin, and two municipalities. Therefore, three reservoirs on the upstream of Yongding River have been used as the water supply for the city since the 1980s. The river channel about $70 \mathrm{~km}$ on the downstream had been dry as a result of the impoundment of the three reservoirs. 
At present, reclaimed water is the "second source of water" in Beijing [3,4], the utilization rate of which has reached to $61 \%$, with the resources of about 800 million $\mathrm{m}^{3}$, used for industrial $\left(160\right.$ million $\left.\mathrm{m}^{3}\right)$ [2], agricultural $\left(200\right.$ million $\left.^{3}\right)$ [5], rivers and lakes landscape (400 million $\left.\mathrm{m}^{3}\right)$ [6], and municipal (greenfield irrigation, car washing, road dust) $\left(40\right.$ million $\left.\mathrm{m}^{3}\right)$ purposes [2]. The dry Yongding River section, whose ecological water demand was about 130 million $\mathrm{m}^{3}$, had been replenished since 2010 [7]. The reclaimed water $\left(15 \times 10^{4} \mathrm{~m}^{3} /\right.$ day $)$ from the nearby sewage treatment plants was used as the main supplementary water source, through $20 \mathrm{~km}$ of circulating pipeline and three pumping stations. The recovered surface water area of Yongding River was about 2.7 million $\mathrm{m}^{2}$. Reclaimed water is derived from treated wastewater used for a certain purpose after treatment. Due to the different treatment processes and discharge standards, some chemical components in reclaimed water are too high, which may cause the potential risk of environmental pollution. The effluents discharged from wastewater treatment plants (WWTPs) could be an important source of nutrient loading and contribute to water eutrophication [8] due to excess nutrients $[9,10]$. Further, it caused the risk of groundwater contamination by infiltration [11], and led to an increase in salt content in the soil, which affected plant growth and caused accumulation of heavy metals in the soil [12,13].

The characteristics of water quality could be identified by multivariate analysis and ionic relationships. The reduction of a large number of water parameters, especially the key ones, could be ascertained by principal component analysis, and the influencing factors of water chemistry could be further inferred [14-18]. Concurrently, the spatio-temporal variations of water quality could also be understood according to the cluster analysis [19-21]. In addition, the dissolved ions and their relationships were effective tools to deduce dissolution of minerals [22-25]. The comprehensive use of multiple methods would be more useful to confirm the characteristics and governing factors of water chemistry. The dry Yongding River section replenished by reclaimed water would face complex environmental issues, and therefore it is important to understand the water quality character and influencing factors. This study can further be beneficial for recovering the river by the reclaimed water.

The main objectives of our study are (1) to understand the physical and chemical compositions of the river water; (2) to illustrate the spatio-temporal variations of water chemistry; and (3) to identify the controlling factors of water chemistry evolution in Yongding River replenished by the reclaimed water.

\section{Materials and Methods}

\subsection{Study Site}

Yongding River is the largest river in the Haihe River Basin [26]. The study site, with an obvious continental climate, is located between the eastern humid zone and the western arid area, where average annual rainfall is about $556-560 \mathrm{~mm}$, with large variations, mainly concentrated from June to September (from 1954 to 2010). The average relative humidity and annual potential evapotranspiration is $57 \%$ and $1890 \mathrm{~mm}$, respectively. The terrain of Yongding River in Beijing section was high in north and low in south. The river above the Sanjiadian Reservoir is $92 \mathrm{~km}$ long, with an average slope of $3.1 \%$, having a mountain erosion structural landform. The middle section (from Sanjiadian Reservoir to the Lugou Bridge), with a length of about $17 \mathrm{~km}$, gradually falls from the mountains into the low mountains and plains. The downstream (from Lugou Bridge to Lianggouzhuang), with a length of $61 \mathrm{~km}$, gradually widens and becomes the sandy river floodplain. The upper reaches of the Yongding River in Beijing contain mountain brown soil; the middle reaches that pass through urban area are mostly brownish yellow clay of volcanic rocks and carbonate rocks, and the main parent soil material is alluvial sediment, primarily in fluvo-aquic soil.

Since the 1980s, the following section of the reservoir had been dry for many years, where the main river section is about $17.4 \mathrm{~km}$, and the river ecosystem had been transformed into a terrestrial ecosystem from 1980 to 2010. In order to recover the river, replenishment of the reclaimed water to the Yongding River has been carried out from 2010 [27]. The main source of replenishment is reclaimed water, followed by rainwater and surface runoff in rainy season $\left(300 \times 10^{4} \mathrm{~m}^{3} /\right.$ year, obtained from 
Beijing Water Conservancy Planning and Design Institute). There is a small tributary with perennial water from the surrounding residential area in the left bank of the river, located between the monitoring station YD05 and YD06 (Figure 1), which is mainly composed of the emissions of cooling water from Beijing Jingxi Gas Thermal Power Co., Ltd. (Beijing, China). The sluice gate of Sanjiadian Reservoir has been closed from the 1980s, and the dry river section is not replenished by the reservoir (Figures 1 and 2). The illustration of the replenishment of the reclaimed water to Yongding River is shown in Figure 2. Firstly, the reclaimed water from the surrounding WWTPs is replenished to the lower reach of the river (station YD10), and then to the upstream with three replenishment points through the pumping stations and water pipes. The replenishment is only from May to October, and the three outlet flows (red arrow positions in Figure 2) are $4 \times 10^{4}, 8 \times 10^{4}$, and $3 \times 10^{4} \mathrm{~m}^{3} /$ day, respectively (Figure 2). The pipes of the three outlet flows are directly set at nearly the bottom of the river, which only could be seen in dry seasons.

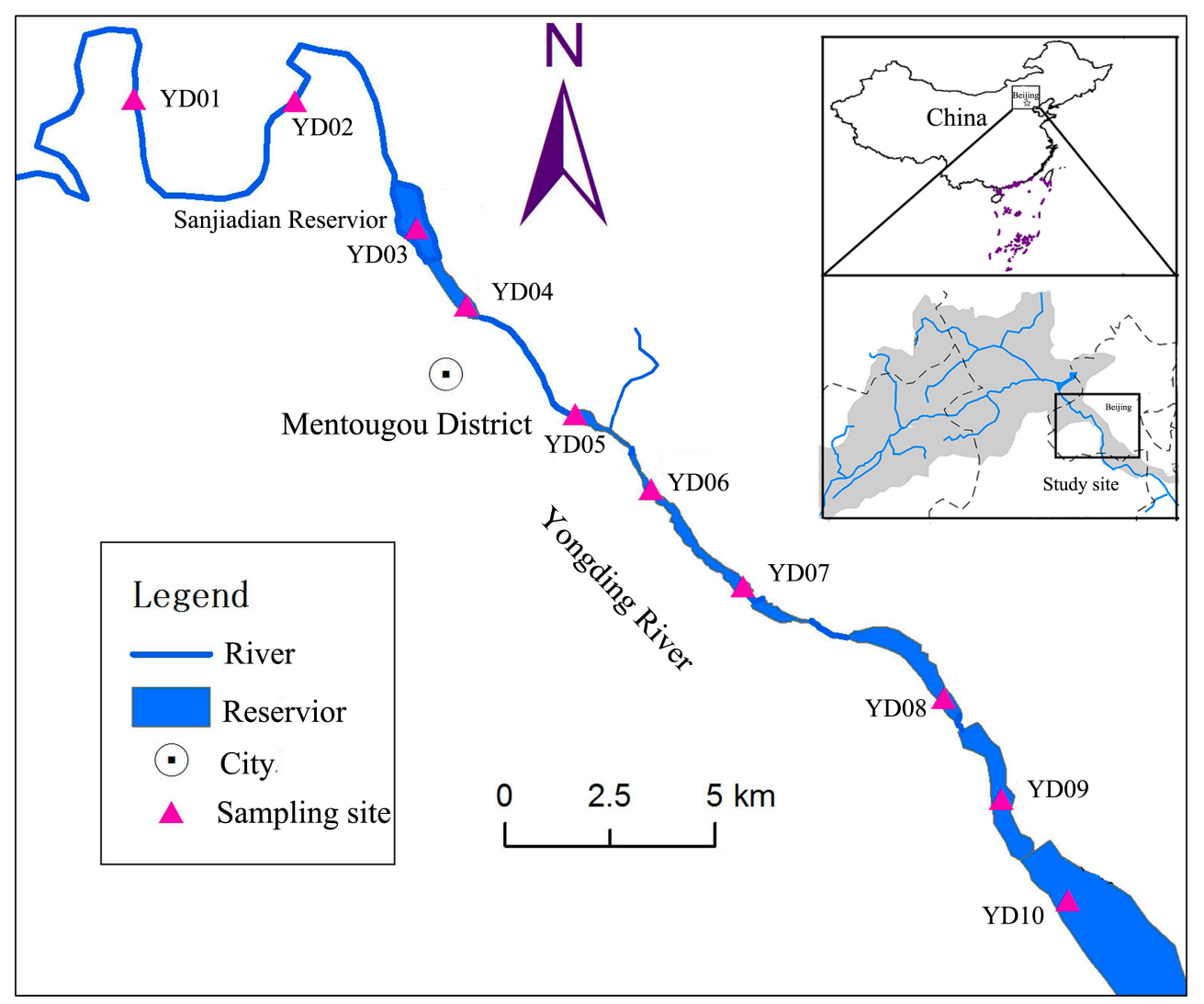

Figure 1. The location of study site and sampling map of river water. 


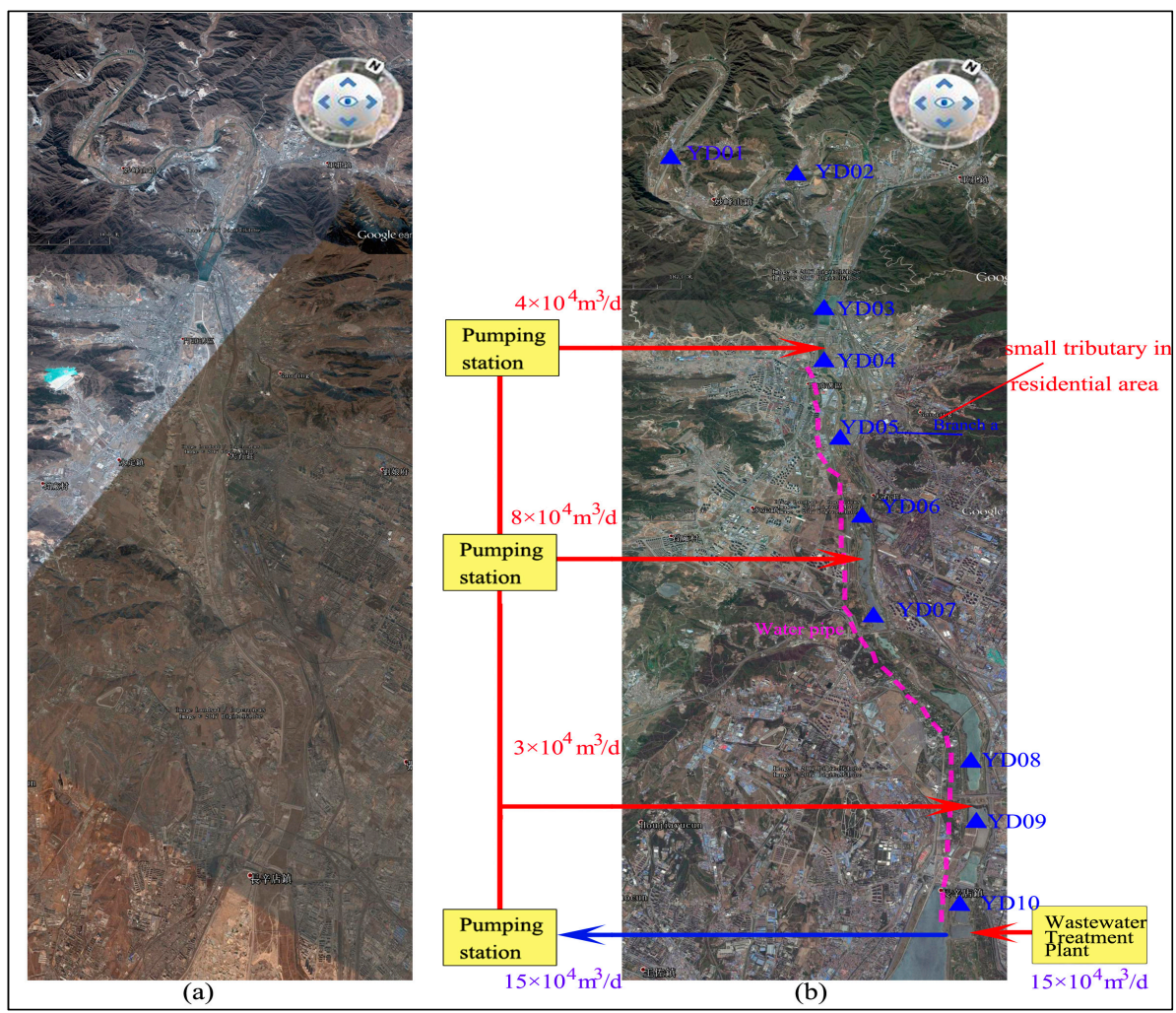

Figure 2. The illustration of the replenishment of reclaimed water to Yongding River (a) represents the dry river channel before the replenishment; (b) represents the river replenished by the reclaimed water, and the background imagines are obtained from the Google earth software).

\subsection{Methods}

\subsubsection{Water Sampling}

In order to investigate the water quality and the controlling factors of river water in Yongding River, samples along the river were collected during spring (April), summer (July), autumn (October), and winter (January) in the year 2015. The study site and monitoring stations are shown in Figures 1 and 2. The natural river section (relative to the river section of reclaimed water) on the upstream included three stations (YD01, YD02, and YD03), and where YD03 is a reservoir. Downstream, the river section replenished by the reclaimed water (treated wastewater) included seven stations (from YD04 to YD10). The natural river section could be the controlling part for further understanding the river replenished by reclaimed water.

\subsubsection{Analytical Techniques}

$\mathrm{pH}$, water temperature $\left(\mathrm{T},{ }^{\circ} \mathrm{C}\right)$, dissolved oxygen $(\mathrm{DO})$, electric conductivity (EC), and oxidation-reduction potential (ORP, Eh) were measured by the portable multi-parameter water quality analyzer (American Hach HQ-40d) produced by Hach Company (Loveland, CO, USA). Water samples were collected, then taken back to the laboratory under $4{ }^{\circ} \mathrm{C}$ cold storage, and analyzed within $24 \mathrm{~h}$. Bicarbonate $\left(\mathrm{HCO}_{3}{ }^{-}\right)$was determined by titration under addition of sulfuric acid $(0.02 \mathrm{~mol} / \mathrm{L})$, and endpoint titration with methyl orange as indicator. Water samples were filtered through a $0.45 \mu \mathrm{m}$ Millipore membrane filter before analysis. The main cations including potassium $\left(\mathrm{K}^{+}\right)$, sodium $\left(\mathrm{Na}^{+}\right)$, calcium $\left(\mathrm{Ca}^{2+}\right)$, magnesium $\left(\mathrm{Mg}^{2+}\right)$, and other trace metals were measured by inductively coupled plasma spectroscopy (ICP-OES), with a detection limit of $0.01 \mathrm{mg} / \mathrm{L}$ and $0.01 \mu \mathrm{g} / \mathrm{L}$ (trace elements). The main anions including fluoride $\left(\mathrm{F}^{-}\right)$, chloride $\left(\mathrm{Cl}^{-}\right)$, sulfate $\left(\mathrm{SO}_{4}{ }^{2-}\right)$ and nitrate $\left(\mathrm{NO}_{3}{ }^{-}\right)$were 
measured by ion chromatograph (Thermo Fisher ICS2100) produced by DIONEX company (Sunnyvale, $\mathrm{CA}, \mathrm{USA})$, and the detection limit was $0.01 \mathrm{mg} / \mathrm{L}$. Ammonia nitrogen $\left(\mathrm{NH}_{3}-\mathrm{N}\right)$, nitrite nitrogen $\left(\mathrm{NO}_{2}-\mathrm{N}\right)$ and soluble reactive phosphorus (SRP) were measured with AMS's Smartchem 200 batch analyzer produced by Alliance company (Paris, France), with detection limits of $0.01 \mathrm{mg} / \mathrm{L}$.

\subsubsection{Data Analysis}

The data of cations and anions require a balance error of less than $5 \%$ before being allowed for further analysis, otherwise the data would be re-measured until the equilibrium error is met. The saturation index of rock mineral was calculated by PHREEQC software. The normality of water chemistry data was checked first using SPSS16.0 software from International Business Machines Corporation (Armonk, NY, USA), then, the data (except $\mathrm{pH}$ ) were log-transformed and standardized before further analysis [28,29]. Analysis of Variance (ANOVA), hierarchical clustering analysis (HCA), and principal component analysis (PCA) were all done using SPSS (SPSS16.0 for Windows). The other graphs were completed using Origin 8.5 software from OriginLab Corporation (Hampton, MA, USA).

The $\mathrm{pE}$ represents the negative logarithm of electron activity, which is calculated in Equation (1) as [30]

$$
p E=\frac{E h F}{2.303 R T}
$$

where, $F$ is Faraday's constant $\left(96.42 \mathrm{kJV}^{-1} \mathrm{~g}^{-1}\right.$ equivalent $), R$ is the gas constant $\left(8.314 \mathrm{Jmol}^{-1} \mathrm{deg}^{-1}\right)$, and $T$ is the absolute temperature in Kelvin.

\section{Results and Discussion}

\subsection{Physical and Chemical Compositions}

The results of physical and chemical compositions of water samples in Yongding River are given in Table 1. The $\mathrm{pH}$ value ranged from 8.32 to 10.32, with mean value of 9.46, which showed that all waters were alkaline. The water temperature ranged from 1 to $31.2{ }^{\circ} \mathrm{C}$, with an average of $15.0^{\circ} \mathrm{C}$, which was mainly influenced by temperature change. The value of EC was not high, with an average of $832 \mu \mathrm{S} / \mathrm{cm}$ (the variation: from 391 to $1278 \mu \mathrm{S} / \mathrm{cm}$ ). The mean value of DO was higher than $10 \mathrm{mg} / \mathrm{L}$, and ranged from 6.49 to $18.0 \mathrm{mg} / \mathrm{L}$. The values of ORP were mostly positive, except three samples (YD10 in spring, YD02 and YD08 in summer), which indicated oxidation water environment. Nitrogen and phosphorus are the main nutrients in river water, and the order of nitrogen forms in natural river water and water replenished by reclaimed water was the same: $\mathrm{NO}_{3}-\mathrm{N}>\mathrm{NH}_{3}-\mathrm{N}>\mathrm{NO}_{2}-\mathrm{N}$, which implied that the nitrate-nitrogen was the main form. The phosphorus in most samples was below the detection level, except YD06 in spring $(0.18 \mathrm{mg} / \mathrm{L})$ and summer $(0.13 \mathrm{mg} / \mathrm{L})$. The order of dominance of major anions in both sections was the same: $\mathrm{HCO}_{3}{ }^{-}>\mathrm{SO}_{4}{ }^{2-}>\mathrm{Cl}^{-}$. The order of major cations in natural river water was $\mathrm{Na}^{+}>\mathrm{Mg}^{2+}>\mathrm{Ca}^{2+}>\mathrm{K}^{+}$, and the order in river water replenished by reclaimed water was $\mathrm{Na}^{+}>\mathrm{Ca}^{2+}>\mathrm{Mg}^{2+}>\mathrm{K}^{+}$. The order of trace metal elements in both was consistent: $\mathrm{Sr}>\mathrm{Ba}$ $>\mathrm{Li}>\mathrm{Fe}>\mathrm{Se}$. The highest value of C.V. in natural water was $\mathrm{SiO}_{2}$, and the one in the other section was $\mathrm{NO}_{2}-\mathrm{N}$.

Some parameters in river water replenished by reclaimed water were clearly higher than the ones in the natural river water, which included $\mathrm{DO}, \mathrm{EC}$, metallic element $\left(\mathrm{K}^{+}, \mathrm{Ca}^{2+}, \mathrm{Sr}, \mathrm{Ba}, \mathrm{Li}, \mathrm{Se}\right)$, anions $\left(\mathrm{Cl}^{-}, \mathrm{SO}_{4}{ }^{2-}\right)$, and nitrogen forms $\left(\mathrm{NH}_{3}-\mathrm{N}, \mathrm{NO}_{2}-\mathrm{N}, \mathrm{NO}_{3}-\mathrm{N}\right)$. The opposite ones included $\mathrm{Fe}$ and $\mathrm{SiO}_{2}$, and the other water chemistries were close in both sections.

According to surface water environmental quality standards (GB3838-2002) in China [31], Class I is for the source of water, the National Nature Reserve; Class II is for centralized drinking water surface water source with the first level protected areas, rare aquatic habitat; Class III is for centralized drinking water surface water source with second level protected areas; Class IV is for the general industrial water area and entertainment water area with indirect contact; Class V is for the agricultural water area and the general landscape requirements of the waters. Based on this standard, the average $\mathrm{pH}$ 
exceeded the standard value; DO met the surface water Class I; $\mathrm{NH}_{3}-\mathrm{N}$ met Class II; Total phosphorus in YD06 in Spring and Summer exceeded Class V; and $\mathrm{F}^{-}$met Class IV. The standard for reclaimed wastewater reused as scenic water (CJ/T 95-2000) in China includes two categories [32]: Class I is for entertainment landscape water with non-systemic contact with skin; Class II is for ornamental landscape water that does not involve the liquid coming into contact with skin. Most parameters met Class II.

Table 1. The results of physical and chemical composition of Yongding River water samples

\begin{tabular}{|c|c|c|c|c|c|c|c|c|c|c|}
\hline \multirow{2}{*}{ Parameters } & \multicolumn{5}{|c|}{ Natural River Water } & \multicolumn{5}{|c|}{ River Replenished by Reclaimed Water } \\
\hline & Min & $\operatorname{Max}$ & Mean & SD & C.V. (\%) & Min & $\operatorname{Max}$ & Mean & SD & C.V. (\%) \\
\hline $\mathrm{pH}$ & 8.58 & 10.32 & 9.55 & 0.62 & 6.52 & 8.32 & 10.15 & 9.38 & 0.59 & 6.30 \\
\hline $\mathrm{T}\left({ }^{\circ} \mathrm{C}\right)$ & 1.0 & 24.0 & 13.7 & 8.48 & 61.96 & 1.4 & 31.2 & 16.4 & 9.15 & 55.95 \\
\hline $\mathrm{EC}(\mu \mathrm{S} / \mathrm{cm})$ & 391 & 1003 & 755 & 165.85 & 21.97 & 430 & 1278 & 910 & 220.77 & 24.27 \\
\hline $\mathrm{DO}(\mathrm{mg} / \mathrm{L})$ & 6.49 & 14.68 & 10.43 & 2.42 & 23.18 & 7.15 & 18.00 & 11.30 & 2.54 & 22.48 \\
\hline ORP (mv) & -6.00 & 230.70 & 124.59 & 75.25 & 60.40 & -121.70 & 215.20 & 124.08 & 84.43 & 68.05 \\
\hline $\mathrm{NH}_{3}-\mathrm{N}(\mathrm{mg} / \mathrm{L})$ & 0.10 & 0.42 & 0.26 & 0.10 & 39.80 & 0.04 & 1.70 & 0.36 & 0.30 & 81.68 \\
\hline $\mathrm{NO}_{2}-\mathrm{N}(\mathrm{mg} / \mathrm{L})$ & 0.00 & 0.03 & 0.01 & 0.01 & 95.35 & 0.00 & 0.35 & 0.05 & 0.09 & 168.52 \\
\hline $\mathrm{NO}_{3}-\mathrm{N}(\mathrm{mg} / \mathrm{L})$ & 0.37 & 1.59 & 0.76 & 0.38 & 50.67 & 0.39 & 14.11 & 2.14 & 3.38 & 157.64 \\
\hline $\mathrm{F}^{-}(\mathrm{mg} / \mathrm{L})$ & 0.24 & 3.05 & 1.19 & 1.13 & 94.83 & 0.07 & 3.45 & 1.17 & 1.21 & 103.5 \\
\hline $\mathrm{Cl}^{-}(\mathrm{mg} / \mathrm{L})$ & 28.78 & 160.55 & 60.46 & 39.92 & 66.02 & 19.92 & 214.18 & 77.60 & 54.12 & 69.74 \\
\hline $\mathrm{SO}_{4}^{2-}(\mathrm{mg} / \mathrm{L})$ & 32.86 & 188.91 & 80.99 & 47.35 & 58.47 & 61.21 & 688.27 & 187.47 & 141.94 & 75.71 \\
\hline $\mathrm{HCO}_{3}{ }^{-}(\mathrm{mg} / \mathrm{L})$ & 198 & 415 & 325 & 74.15 & 22.83 & 116 & 387 & 230 & 76.39 & 33.22 \\
\hline $\mathrm{K}^{+}(\mathrm{mg} / \mathrm{L})$ & 1.83 & 6.15 & 3.47 & 1.30 & 37.39 & 3.01 & 17.52 & 9.14 & 4.67 & 51.13 \\
\hline $\mathrm{Na}^{+}(\mathrm{mg} / \mathrm{L})$ & 30.37 & 106.50 & 59.00 & 23.26 & 39.42 & 18.63 & 101.00 & 59.28 & 25.41 & 42.87 \\
\hline $\mathrm{Ca}^{2+}(\mathrm{mg} / \mathrm{L})$ & 4.50 & 15.37 & 9.55 & 2.82 & 29.50 & 12.70 & 78.20 & 31.26 & 15.35 & 49.12 \\
\hline $\mathrm{Mg}^{2+}(\mathrm{mg} / \mathrm{L})$ & 11.26 & 36.97 & 25.83 & 9.43 & 36.53 & 9.95 & 51.73 & 24.69 & 9.62 & 38.95 \\
\hline $\mathrm{Al}(\mathrm{mg} / \mathrm{L})$ & 0.01 & 0.07 & 0.03 & 0.02 & 66.95 & 0.00 & 0.06 & 0.02 & 0.01 & 76.92 \\
\hline $\mathrm{B}(\mathrm{mg} / \mathrm{L})$ & 0.05 & 0.17 & 0.10 & 0.04 & 36.32 & 0.02 & 0.15 & 0.07 & 0.03 & 47.14 \\
\hline $\mathrm{Sr}(\mu \mathrm{g} / \mathrm{L})$ & 140.4 & 296.4 & 185.2 & 43.3 & 23.37 & 214.6 & 3083.0 & 714.2 & 611.2 & 85.57 \\
\hline $\mathrm{Ba}(\mu \mathrm{g} / \mathrm{L})$ & 10.2 & 41.4 & 27.7 & 8.5 & 30.57 & 24.9 & 87.3 & 49.4 & 15.5 & 31.31 \\
\hline $\mathrm{Fe}(\mu \mathrm{g} / \mathrm{L})$ & 0.9 & 32.8 & 10.8 & 9.7 & 90.2 & 1.1 & 32.0 & 10.0 & 7.4 & 74.1 \\
\hline $\operatorname{Li}(\mu \mathrm{g} / \mathrm{L})$ & 6.1 & 18.7 & 11.5 & 4.1 & 36.2 & 3.9 & 52.9 & 16.6 & 12.6 & 75.7 \\
\hline $\mathrm{Se}(\mu \mathrm{g} / \mathrm{L})$ & 0.0 & 16.2 & 7.8 & 4.1 & 52.1 & 2.4 & 17.6 & 9.8 & 4.0 & 41.0 \\
\hline $\mathrm{SiO}_{2}(\mathrm{mg} / \mathrm{L})$ & 0.01 & 7.47 & 2.42 & 2.44 & 100.83 & 0.01 & 4.77 & 0.64 & 1.01 & 157.82 \\
\hline
\end{tabular}

\subsection{Spatial and Temporal Variation of Water Quality}

\subsection{1. $\mathrm{pH}, \mathrm{T}, \mathrm{EC}, \mathrm{DO}$, and ORP}

The variations of $\mathrm{pH}, \mathrm{T}, \mathrm{EC}, \mathrm{DO}$, and ORP are shown in Figure 3. The $\mathrm{pH}$ values in summer and autumn were higher than the ones in spring and winter, except for station YD06. A significant temporal variation was found in YD06, and the highest $\mathrm{pH}$ in spring, while the lowest one was in winter, and the value was close in summer and autumn. A significant seasonal variation of water temperature was ascertained, showing highest temperature in summer, lowest in winter, and moderate in spring and autumn. Water temperature increased gradually along the river, while it was lower in the natural river section than that in the reclaimed water section. The EC in the natural river section was higher in winter and lower in summer, while the median was in spring and autumn. The peak and valley value was found in YD06 in winter $(1278 \mu \mathrm{S} / \mathrm{cm})$ and YD01 in summer $(391 \mu \mathrm{S} / \mathrm{cm})$, respectively. The EC in river section of reclaimed water was high in spring and summer, and low in autumn and winter, except for the extreme values. The peak value of DO occurred in YD06 in summer, and the next to highest one was in YD07 in autumn, while the lowest was in YD02 in summer. The obvious seasonal variation of DO in natural river section was the occurrence of high values in winter and low values in summer, while the reverse trend was observed in river section of reclaimed water. The apparent seasonal variation of ORP was: autumn $>$ winter $>$ spring and summer. The lowest ORP value was found in YD10 in spring $(-12.7 \mathrm{mV})$, and the next lower one was in YD08 in summer $(-87.3 \mathrm{mV})$. In winter, the ORP of natural river section was higher than in the section of reclaimed water, while the result was opposite in other seasons. 

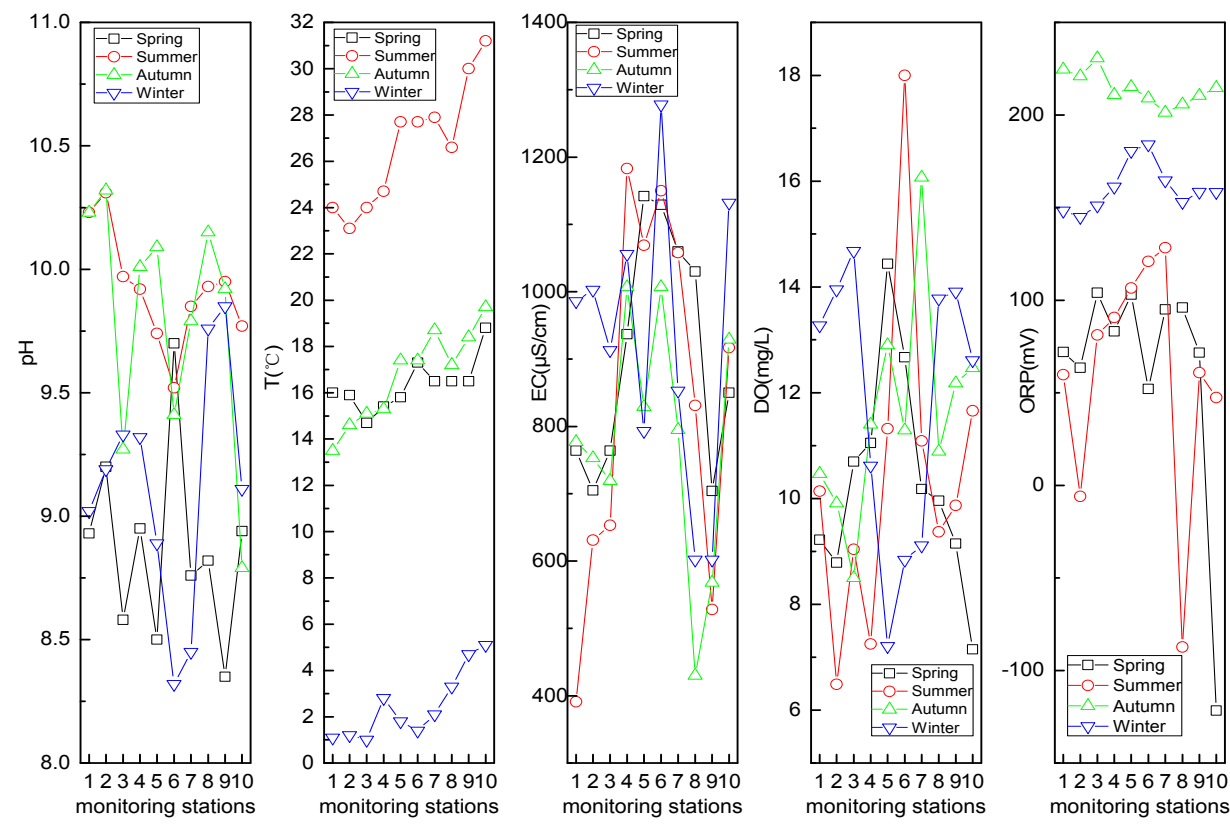

Figure 3. Spatial and temporal variation of $\mathrm{pH}, \mathrm{T}, \mathrm{EC}, \mathrm{DO}$, and ORP in Yongding River.

\subsubsection{Nitrogen and Phosphorus}

Spatial and temporal variations of nitrogen in Yongding River are presented in Figure 4. The value of $\mathrm{NH}_{3}-\mathrm{N}$ was lower in spring, and higher in summer and autumn. The peak $\mathrm{NH}_{3}-\mathrm{N}$ value appeared in YD06 in summer, and the valley value appeared in YD05 in spring. $\mathrm{NH}_{3}-\mathrm{N}$ in natural river sections was mostly lower than the one in the section of reclaimed water. The $\mathrm{NO}_{2}-\mathrm{N}$ was quite low in river water, except for the value of YD06 in spring $(0.35 \mathrm{mg} / \mathrm{L})$. The $\mathrm{NO}_{3}-\mathrm{N}$ in most stations ranged from 0 to $2 \mathrm{mg} / \mathrm{L}$, except for YD06 and YD07. The highest and the second highest values appeared in YD06 in autumn and winter, respectively. The peak values of three nitrogen forms were all found in YD06 in different seasons. Phosphorus only occurred in YD06 in spring and summer, which was not described in the figure.
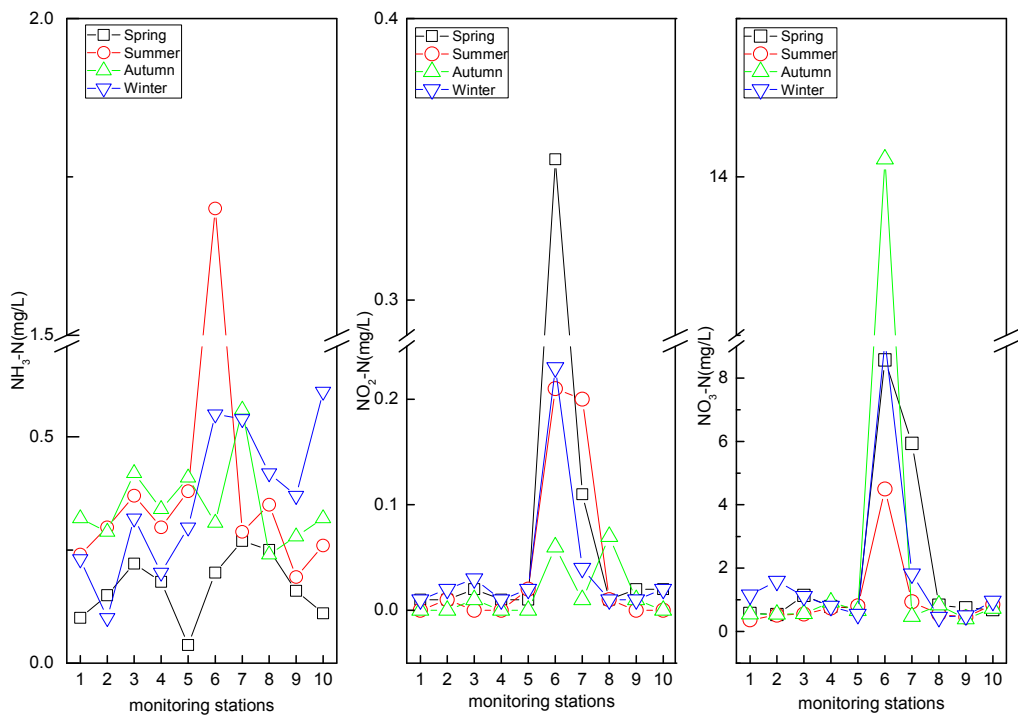

Figure 4. Spatial and temporal variation of Nitrogen in Yongding River. 


\subsubsection{Major Cations and Anions}

Spatial and temporal variations of major cations and anions are depicted in Figure $5 . \mathrm{F}^{-}$in spring was quite low, and the content was very different among monitoring stations. The $\mathrm{Cl}^{-}$and $\mathrm{SO}_{4}{ }^{2-}$ in natural river water were higher in summer. The peak values of $\mathrm{Cl}^{-}$and $\mathrm{SO}_{4}{ }^{2-}$ occurred in YD04 in autumn, and the next highest appeared in YD10 in summer and YD06 in autumn, respectively. The higher value of $\mathrm{Cl}^{-}$in YD06 and YD07 in four seasons was another apparent feature. The $\mathrm{SO}_{4}{ }^{2-}$ in winter was lower than in other seasons. The $\mathrm{HCO}_{3}{ }^{-}$in autumn was higher, and quite low in summer, and the value in natural river section was higher except in summer. The significant variation of $\mathrm{K}^{+}$ was the peak value in YD06 and YD07 in four seasons. $\mathrm{Na}^{+}$was similar to $\mathrm{K}^{+}$except the peak value of YD01 in autumn. The $\mathrm{Ca}^{2+}$ in natural river water was obviously higher than in the section of reclaimed water. The $\mathrm{Ca}^{2+}$ gradually increased from YD04 to YD07, then decreased slowly from YD08 to YD10, and the peak value occurred in YD06 in summer. The peak of $\mathrm{Mg}^{2+}$ appeared in YD04 in summer, and the valley occurred in YD01 in summer. Meanwhile, the content in winter was high and low in summer.
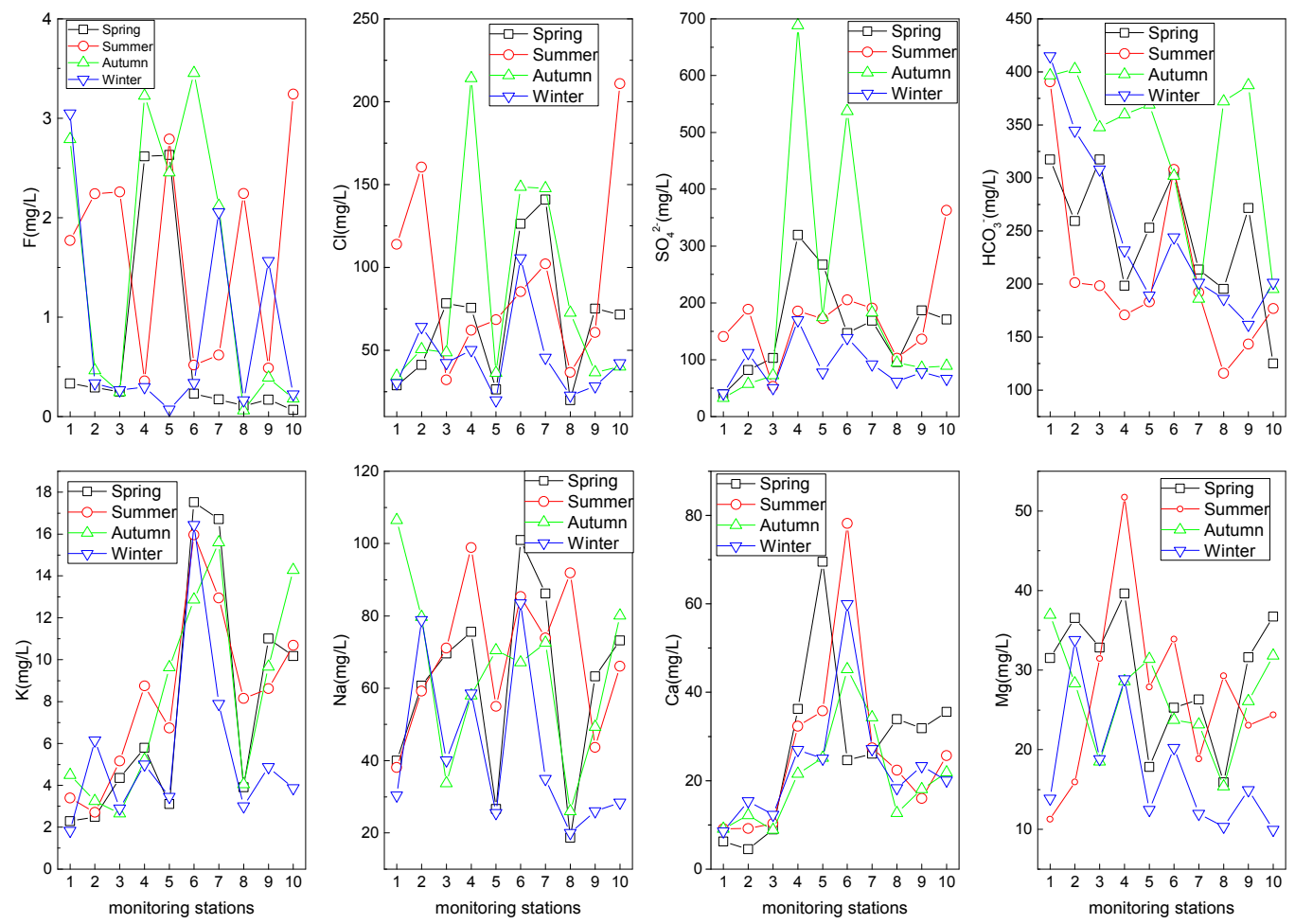

Figure 5. Spatial and temporal variation of major cations and anions in Yongding River.

\subsubsection{Trace Metallic Elements}

Spatio-temporal variation of trace metallic elements is shown in Figure 6. Similar variation of Al was identified in four seasons, which was the valley stage from YD04 to YD06. The peak value appeared in YD03 in autumn. B content was low in winter and high in summer, where peak and valley occurred in YD01 in autumn and YD05 in spring and winter, respectively. Li content was low in winter, where a rising stage occurred in YD04 and YD05 in all seasons. The peak of $\mathrm{SiO}_{2}$ appeared in YD01 in summer, and there are two other next highest peaks in YD03 and YD08. The peak and valley of As occurred in YD04 in winter and YD03 in spring, respectively. An increasing of Sr sharply occurred from YD04 to YD06, and the maximum value appeared in YD05 in spring, while other values were quite low. Seasonal variation of Ba was not significant, and spatial variations increased along the river except in station YD03. The clear variation was that the increasing and peak value occurred in 
reservoir (YD03), and the content in YD01 and YD02 on upstream natural river section was very low, while higher values of YD09 and YD10 occurred downstream.
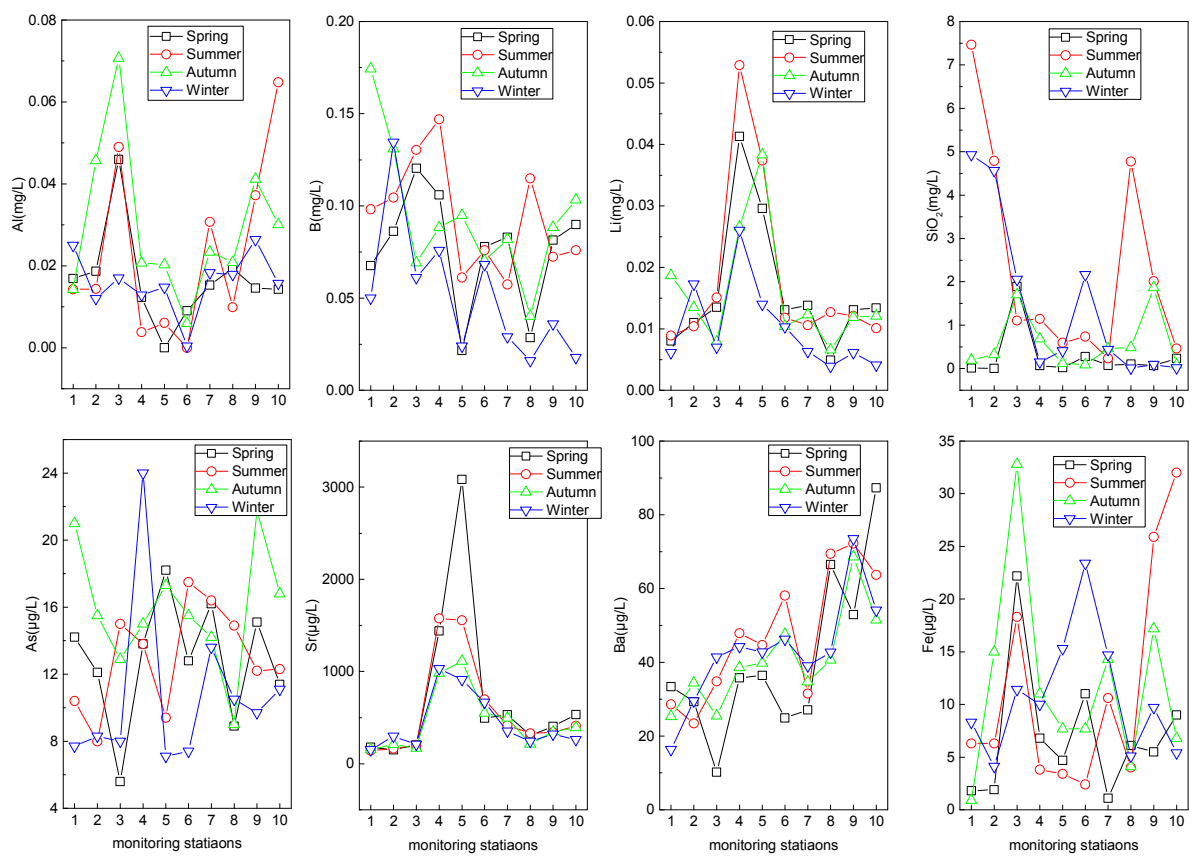

Figure 6. Spatial and temporal variation of trace metallic elements in Yongding River.

\subsection{Cluster Analysis and Spatio-Temporal Similarity}

In order to identify the seasonal variation, the results analyzed by cluster analysis are shown in Figure 7. Four seasons were classified into two groups both in the natural river section and the reclaimed water section. Group A included spring, summer, and autumn, and Group B included winter in both sections. The distinct groups showed significant seasonal variation, and winter was particularly apparent from other seasons. The water temperatures described in Figure 3 presented the normal decrease in winter, which was a critical factor influencing some chemical reactions.

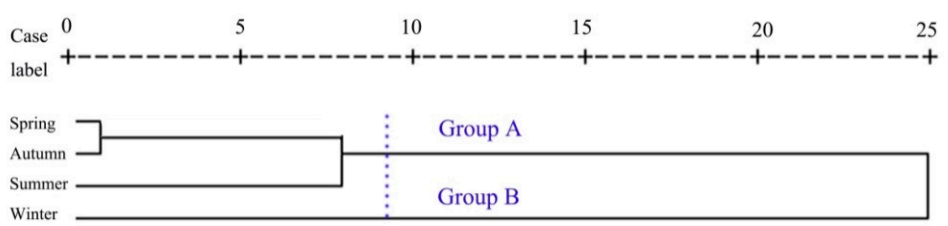

(a)

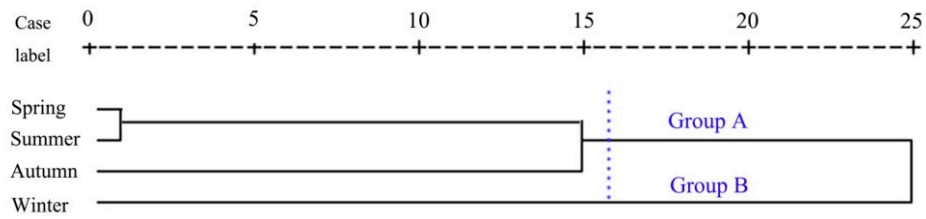

(b)

Figure 7. Temporal cluster analysis in the natural river section (a) and the section replenished by reclaimed water $(\mathbf{b})$.

Therefore, the parameters with significant difference, which were identified by $t$-test of two independent samples using SPSS, are shown in Table 2. In the natural river section, the ones including 
$\mathrm{T}$ and As were clearly higher in Group A than in Group B, and the others including EC, DO, and $\mathrm{NO}_{3}-\mathrm{N}$ were opposite. In the reclaimed water section, the parameters $\mathrm{T}, \mathrm{Cl}^{-}, \mathrm{SO}_{4}{ }^{2-}, \mathrm{Na}^{+}, \mathrm{Mg}^{2+}$, and $\mathrm{B}$ in Group A were remarkably higher than in Group B, in contrary to ORP. Saturated dissolved oxygen in pure water is usually $10 \mathrm{mg} / \mathrm{L}$ under the conditions of $25^{\circ} \mathrm{C}$ and an atmospheric pressure [33,34]. The solubility of DO in winter would increase due to the lower temperature and higher atmospheric pressure [33,34]. The DO content in river water is influenced by many factors, such as hydrodynamic conditions, phytoplankton photosynthesis, and degradation of organic matter [35-38]. Most DO contents of river water in our research were more than $10 \mathrm{mg} / \mathrm{L}$ [33]. This could be influenced by the photosynthesis of phytoplankton (aquatic plant and algae). Meanwhile, the organic degradation in summer with high temperature would consume more oxygen than in other seasons. In our study, the $\mathrm{BOD}_{5}$ was not analyzed, but the close value $\left(\mathrm{BOD}_{5}: 20 \mathrm{mg} / \mathrm{L}\right)$ could be obtained from the discharge standard (CJ/T 95-2000) in China. Usually, the decomposition of 162g carbohydrates needs to consume $192 \mathrm{mg}$ oxygen in water. As a result, the organic with $20 \mathrm{mg} / \mathrm{L}$ would consume $23.7 \mathrm{mg} / \mathrm{L}$ of DO [35]. Therefore, the DO in summer was lower than in other seasons in our study. DO is the main constituent of the oxidation capacity, therefore, higher ORP occurred in winter. Although the reclaimed water had high content of major ions, the content would be diluted by the rainfall and surface runoff.

Table 2. The parameters with significant difference of temporal clusters in Yongding River

\begin{tabular}{|c|c|c|c|c|c|c|c|c|}
\hline & & $\mathbf{T}$ & EC & DO & $\mathrm{NO}_{3}-\mathrm{N}$ & As & & \\
\hline \multirow[t]{3}{*}{ NR } & Group A & $17.88^{a}$ & $684.11^{a}$ & $9.25^{\mathrm{a}}$ & $0.59^{a}$ & $12.74^{\mathrm{a}}$ & & \\
\hline & Group B & $1.10^{\mathrm{b}}$ & $967.33^{b}$ & $13.97^{b}$ & $1.29^{b}$ & $8.00^{b}$ & & \\
\hline & & $\mathbf{T}$ & ORP & $\mathrm{Cl}^{-}$ & $\mathrm{SO}_{4}{ }^{2-}$ & $\mathrm{Na}$ & Mg & B \\
\hline \multirow[t]{2}{*}{ RR } & Group A & $20.80^{a}$ & $110.18^{a}$ & $88.50^{a}$ & $217.42^{a}$ & $65.85^{a}$ & $27.75^{a}$ & $0.08^{a}$ \\
\hline & Group B & $3.03^{b}$ & $165.79^{b}$ & $44.89^{b}$ & $97.62^{b}$ & $39.56^{b}$ & $15.53^{b}$ & $0.04^{b}$ \\
\hline
\end{tabular}

Notes: NR represents the natural river water, and RR represents the river section replenished by reclaimed water; Means of the same parameter in two groups with the different letter are significantly different $(p<0.05)$.

Spatial variation and similarity were analyzed by HCA analysis (Figure 8). All the monitoring stations were classified into four groups, which included Group A (YD01, YD02, and YD03), Group B (YD04 and YD05), Group C (YD06) and Group D (YD07, YD08, YD09, and YD10). The difference of major ions in the four groups was compared using ANOVA analysis. Most of the parameters except $\mathrm{Li}$, $\mathrm{Sr}$, and B were higher than others. The major ions in the reclaimed water section were higher than the ones in the natural river section. The small tributary from the residential area on the upstream of station YD06 may lead to the increase of the most water quality parameter (Table 3). As a result, the YD06 belonged to the separate group.

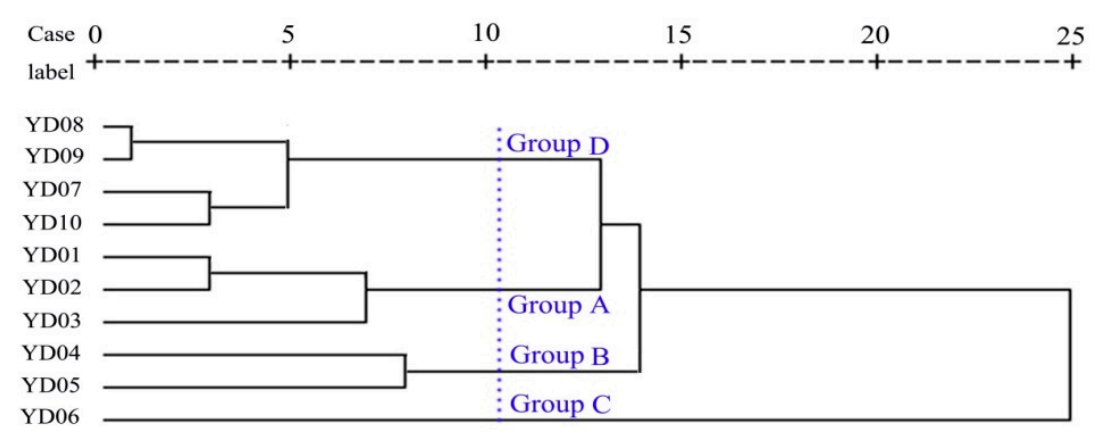

Figure 8. Spatial cluster analysis of monitoring stations in Yongding River. 
Table 3. Difference between spatial clusters using ANOVA analysis.

\begin{tabular}{|c|c|c|c|c|c|c|c|c|c|c|c|c|c|c|c|}
\hline Groups & EC & $\mathrm{K}^{+}$ & $\mathrm{Na}^{+}$ & $\mathrm{Ca}^{2+}$ & $\mathrm{Cl}^{-}$ & $\mathrm{SO}_{4}{ }^{2-}$ & $\mathrm{HCO}_{3}{ }^{-}$ & $\mathrm{NH}_{3}-\mathrm{N}$ & $\mathrm{NO}_{2}-\mathrm{N}$ & $\mathrm{NO}_{3}-\mathrm{N}$ & $\mathrm{SiO}_{2}$ & B & $\mathbf{L i}$ & Sr & Ва \\
\hline Group A & $755^{\mathrm{a}}$ & $3.47^{\mathrm{a}}$ & 59.00 & $9.55^{\mathrm{a}}$ & $60.46^{a}$ & $80.99^{a}$ & $325^{a}$ & $0.26^{\mathrm{a}}$ & $0.01^{\mathrm{a}}$ & $0.77^{\mathrm{a}}$ & $2.42^{a}$ & $0.10^{\mathrm{a}}$ & $11.45^{b}$ & $185.20^{\mathrm{a}}$ & $27.68^{a}$ \\
\hline Group B & $1002^{b}$ & $5.96^{\mathrm{a}}$ & 58.58 & $34.06^{\mathrm{b}}$ & $69.15^{\mathrm{a}}$ & $256.88^{\mathrm{b}}$ & $244^{b}$ & $0.27^{\mathrm{a}}$ & $0.01^{\mathrm{a}}$ & $0.75^{\mathrm{a}}$ & $0.40^{\mathrm{b}}$ & $0.08^{a b}$ & $33.26^{a}$ & $1461.55^{\mathrm{ab}}$ & $41.28^{b}$ \\
\hline Group C & $1141^{\mathrm{b}}$ & $15.70^{\mathrm{ab}}$ & $84.26^{a}$ & $52.00^{\mathrm{ab}}$ & $116.45^{b}$ & $256.97^{b}$ & $290^{\mathrm{b}}$ & $0.69^{b}$ & $0.21^{b}$ & $9.21^{b}$ & $0.82^{b}$ & $0.07^{\mathrm{ab}}$ & $11.40^{\mathrm{b}}$ & $601.15^{b}$ & $44.20^{\mathrm{b}}$ \\
\hline Group D & 806 & $9.09^{b}$ & $53.38^{b}$ & $24.67^{a b c}$ & $67.90^{\mathrm{a}}$ & $135.39^{a b}$ & $208^{a b}$ & $0.33^{a}$ & $0.03^{a}$ & $1.07^{\mathrm{a}}$ & $0.71^{b}$ & $0.06^{b}$ & $9.63^{b}$ & $368.77^{a b c}$ & $54.71^{\mathrm{ab}}$ \\
\hline
\end{tabular}

Note: Means of the same parameter in four groups with the different letter are significantly different $(p<0.05)$ 
The water quality parameters with significant changes among four groups are shown in Table 3, and the ones with no significant changes are not listed. In the reclaimed water section, the most parameters showed the trend of first increase and then decrease, which included $\mathrm{EC}, \mathrm{K}^{+}, \mathrm{Na}^{+}, \mathrm{Ca}^{2+}$, $\mathrm{Cl}^{-}, \mathrm{HCO}_{3}{ }^{-}, \mathrm{NH}_{3}-\mathrm{N}, \mathrm{NO}_{2}-\mathrm{N}, \mathrm{NO}_{3}-\mathrm{N}$, and $\mathrm{SiO}_{2}$. Group $\mathrm{C}$ contained only the station $\mathrm{YDO} 6$, where the increase of most ions was caused by the import of the small tributary on the left bank (Figures 1 and 2), whose flow is mainly composed of the emissions of cooling water from Beijing Jingxi Gas Thermal Power Co., Ltd. (Beijing, China). The concentration of ions in Group D was reduced due to the effect of dilution by the mixing of tributary and the river water in main channel. In addition to the effects of dilution, the reduction of $\mathrm{NH}_{3}-\mathrm{N}$ may be caused by the absorption of phytoplankton or nitrification. $\mathrm{NO}_{3}-\mathrm{N}$ had two reduction pathways of reaction, the first was the absorption of phytoplankton, and the second was transformed to $\mathrm{N}_{2}$ by the denitrification. On the other hand, according to the result of Table 1 and Figure 3, the oxidation environment was good for nitrification and against denitrification. Therefore, the major reactions were the absorption of phytoplankton and nitrification for nitrogen. The variation of major cations including $\mathrm{Na}^{+}, \mathrm{K}^{+}$, and $\mathrm{Ca}^{2+}$ may be influenced by the possible ion exchange process.

\subsection{Principal Components and Controlling Factors}

In order to infer the controlling factors, the four spatial clusters were analyzed by principal component analysis (Table 4). The components would be retained if the corresponding eigenvalue $>1$ [39], then the critical related parameters would be kept according to the explaining proportion $>0.60$ [40]. In Group A (the natural river water stations), seven principal components totally explaining $93.93 \%$ were retained. $\mathrm{PC} 1$ had high and positive loading with $\mathrm{EC}, \mathrm{DO}, \mathrm{NO}_{2}-\mathrm{N}, \mathrm{NO}_{3}-\mathrm{N}, \mathrm{Se}$, and Sr, while negative loading with T; PC2 was highly related to $\mathrm{K}, \mathrm{Na}^{+}, \mathrm{Mg}^{2+}, \mathrm{B}$, and $\mathrm{Li}$; PC3 was highly and positively correlated with $\mathrm{Cl}^{-}, \mathrm{SO}_{4}{ }^{2-}$, and $\mathrm{SiO}_{2} ; \mathrm{PC} 4, \mathrm{PC} 5$, and $\mathrm{PC} 6$ had high and positive loading with $\mathrm{Al}, \mathrm{Fe}, \mathrm{F}^{-}$, and $\mathrm{Ba}$; $\mathrm{PC} 5$ was highly related to ORP and $\mathrm{HCO}_{3}{ }^{-}$. High and positive loading occurred with major ions and anions, as well as trace metallic elements, which showed the main chemical composition and dissolution of major minerals [41]. Loading with $\mathrm{NO}_{2}-\mathrm{N}_{1} \mathrm{NO}_{3}-\mathrm{N}$, $\mathrm{DO}$, and ORP indicated that the oxidation water environment and nitrification reaction formed the nitrate [42]. 
Table 4. Results of spatial clusters (Group A, Group B, Group C, and Group D) using principal component analysis.

\begin{tabular}{|c|c|c|c|c|c|c|c|c|c|c|c|c|c|c|c|c|c|c|c|c|c|c|}
\hline \multirow{2}{*}{ Parameters } & \multicolumn{7}{|c|}{ Group A } & \multicolumn{6}{|c|}{ Group B } & \multicolumn{3}{|c|}{ Group C } & \multicolumn{6}{|c|}{ Group D } \\
\hline & PC1 & PC2 & PC3 & PC4 & PC5 & PC6 & PC7 & PC1 & PC2 & PC3 & PC4 & PC5 & PC6 & PC1 & PC2 & PC3 & PC1 & PC2 & PC3 & PC4 & PC5 & PC6 \\
\hline $\mathrm{pH}$ & -0.59 & 0.33 & 0.25 & -0.02 & 0.13 & 0.38 & 0.50 & 0.58 & 0.42 & -0.17 & 0.26 & 0.08 & 0.62 & 0.94 & 0.20 & -0.29 & -0.05 & 0.15 & 0.30 & 0.19 & -0.09 & 0.23 \\
\hline $\mathrm{T}$ & 0.89 & 0.12 & 20 & 0.12 & 0.33 & -0.03 & 0.03 & 0.59 & -0.45 & 0.15 & 0.17 & -0.35 & 0.52 & 0.97 & 0.07 & 0.22 & 0.50 & -0.30 & 0.52 & 0.40 & 0.04 & 0.26 \\
\hline EC & 0.88 & 0.05 & -0.35 & -0.04 & 0.09 & 0.05 & -0.08 & 0.19 & -0.83 & -0.28 & 0.33 & 0.24 & 0.15 & 0.25 & 0.48 & 0.48 & 0.01 & 0.65 & 0.06 & 0.06 & 0.42 & 0.31 \\
\hline DO & 0.82 & -0.03 & -0.05 & -0.15 & 0.41 & 0.07 & 0.17 & -0.10 & -0.26 & 0.87 & 0.13 & 0.31 & 0.18 & 0.81 & 0.26 & 0.53 & -0.08 & -0.11 & 0.19 & 0.85 & -0.14 & -0.16 \\
\hline ORP & 21 & 0.20 & -0.45 & 0.43 & 0.68 & 0.02 & 0.11 & -0.28 & 0.82 & 0.10 & 0.11 & 0.33 & 0.32 & -0.36 & -0.92 & 0.15 & -0.14 & -0.20 & -0.03 & 0.69 & 0.14 & -0.63 \\
\hline $\mathrm{NH}_{3}-\mathrm{N}$ & .27 & 0.01 & -0.02 & 0.77 & & 0.43 & & 0.32 & 0.64 & -0.17 & 0.01 & -0.29 & 0.60 & 0.37 & 0.07 & 0.93 & -0.24 & 0.12 & -0.19 & 0.87 & 0.09 & 0.22 \\
\hline $\mathrm{NO}_{2}-\mathrm{N}$ & 0.78 & -0.25 & 0.13 & 0.00 & -0.21 & -0.34 & 0.01 & -0.58 & -0.14 & -0.09 & -0.34 & -0.56 & -0.12 & -0.14 & 0.99 & -0.08 & 0.05 & -0.05 & 0.11 & -0.11 & 0.88 & -0.04 \\
\hline $\mathrm{NO}_{3}-\mathrm{N}$ & 0.96 & 0.14 & 0.13 & -0.04 & 0.08 & -0.08 & -0.16 & 0.27 & -0.18 & 0.10 & 0.85 & 0.16 & 0.03 & -0.24 & -0.68 & -0.69 & 0.16 & 0.28 & -0.01 & -0.09 & 0.71 & -0.09 \\
\hline $\mathrm{F}^{-}$ & -0.21 & 0.09 & 0.09 & -0.14 & 0.03 & 0.94 & -0.14 & 0.11 & -0.10 & 0.80 & 0.49 & -0.20 & 0.23 & & & & 0.13 & 0.01 & 0.51 & 0.40 & -0.18 & 0.57 \\
\hline $\mathrm{Cl}^{-}$ & -0.28 & 0.02 & 90 & -0.07 & -0.18 & -0.01 & -0.06 & 0.13 & 0.26 & & & -0.03 & 0.09 & 0.28 & -0.89 & -0.36 & 0.29 & 0.17 & 0.84 & & 0.29 & 0.05 \\
\hline $\mathrm{SO}_{4}^{2-}$ & -0.19 & 0.06 & 0.90 & -0.10 & -0.27 & -0.12 & -0.10 & 0.04 & 0.12 & 0.26 & 0.94 & 0.09 & -0.03 & 0.06 & -0.45 & -0.89 & 0.26 & 0.21 & 0.88 & -0.19 & 0.08 & 0.13 \\
\hline $\mathrm{HCO}_{3}^{-}$ & 0.11 & -0.07 & -0.09 & -0.06 & 0.97 & 0.04 & -0.11 & -0.01 & 0.48 & 0.54 & 0.32 & 0.47 & 0.34 & 0.98 & 0.07 & -0.18 & 0.08 & -0.39 & -0.10 & 0.09 & 0.12 & -0.73 \\
\hline $\mathrm{K}^{+}$ & 0.25 & 0.89 & 0.15 & 0.06 & -0.04 & -0.04 & 0.09 & 0.86 & 0.20 & -0.01 & -0.19 & 0.04 & 0.43 & -0.24 & 0.96 & 0.11 & 0.82 & 0.30 & 0.30 & 0.06 & 0.30 & -0.07 \\
\hline $\mathrm{Na}^{+}$ & -0.10 & 0.92 & -0.17 & -0.11 & 0.05 & 0.02 & -0.05 & 0.97 & 0.04 & -0.22 & 0.10 & 0.08 & -0.01 & -0.01 & 1.00 & -0.09 & 0.86 & 0.21 & 0.15 & -0.12 & 0.21 & 0.32 \\
\hline $\mathrm{Ca}^{2+}$ & 55 & 0.47 & 0.35 & 0.22 & 0.26 & 0.02 & 47 & -0.26 & -0.86 & 0.38 & -0.12 & 0.06 & -0.08 & 0.00 & -0.25 & 0.97 & 0.16 & 0.84 & 0.15 & -0.14 & -0.07 & 0.12 \\
\hline $\mathrm{Mg}^{2+}$ & 0 & 0.66 & -0.57 & -0.20 & -0.19 & -0.36 & -0.18 & 0.95 & -0.14 & -0.24 & 0.14 & 0.06 & -0.08 & 0.80 & 0.22 & 0.57 & 0.82 & 0.19 & 0.08 & -0.46 & -0.23 & 0.03 \\
\hline $\mathrm{SiO}_{2}$ & 0.14 & -0.19 & 0.85 & -0.14 & 0.18 & 0.32 & -0.02 & 0.33 & -0.06 & -0.71 & 0.34 & -0.25 & 0.38 & -0.87 & 0.10 & 0.49 & 0.39 & -0.54 & -0.24 & -0.10 & -0.17 & 0.63 \\
\hline $\mathrm{Al}$ & -0.06 & -0.07 & -0.26 & 0.90 & 0.02 & -0.19 & -0.16 & 0.04 & 0.85 & 0.36 & 0.26 & 0.02 & 0.21 & 0.37 & -0.10 & -0.93 & 0.03 & -0.37 & 0.72 & 0.16 & -0.13 & -0.13 \\
\hline B & -0.26 & 0.95 & 0.00 & -0.04 & 0.11 & 0.04 & -0.03 & 0.94 & 0.11 & -0.22 & 0.19 & 0.14 & -0.05 & 0.41 & -0.02 & 0.24 & 0.92 & -0.02 & 0.13 & -0.22 & -0.16 & 0.18 \\
\hline $\mathrm{Li}$ & 0.18 & 0.82 & -0.19 & -0.07 & -0.09 & 0.35 & 0.16 & 0.90 & -0.36 & 0.08 & 0.08 & 0.06 & 0.21 & 0.62 & 0.77 & 0.16 & 0.72 & -0.19 & 0.29 & -0.13 & 0.05 & -0.03 \\
\hline Se & 0.70 & 0.46 & -0.20 & -0.01 & -0.22 & -0.16 & -0.03 & -0.79 & -0.16 & -0.18 & -0.33 & 0.36 & -0.28 & 0.97 & -0.19 & 0.16 & -0.04 & 0.78 & -0.05 & 0.28 & 0.12 & 0.25 \\
\hline As & -0.54 & 0.39 & -0.63 & -0.03 & 0.20 & 0.17 & 0.25 & 0.12 & -0.13 & 0.17 & 0.06 & 0.93 & -0.14 & -0.22 & -0.13 & 0.97 & 0.83 & -0.10 & -0.11 & 0.18 & 0.17 & -0.16 \\
\hline $\mathrm{Sr}$ & 0.67 & 0.51 & 0.11 & 0.10 & -0.05 & -0.38 & 0.27 & -0.17 & -0.89 & 0.35 & -0.07 & 0.08 & 0.03 & 0.12 & -0.56 & 0.82 & 0.64 & 0.56 & 0.32 & -0.17 & 0.16 & 0.03 \\
\hline $\mathrm{Ba}$ & -0.04 & -0.02 & -0.25 & -0.12 & -0.11 & -0.15 & 0.94 & 0.19 & -0.02 & -0.85 & -0.24 & -0.02 & 0.39 & 0.22 & 0.08 & -0.15 & -0.02 & -0.08 & -0.03 & -0.47 & -0.76 & 0.22 \\
\hline $\mathrm{Fe}$ & 0.02 & -0.09 & 0.04 & 0.97 & 0.00 & -0.15 & -0.09 & -0.55 & 0.75 & -0.20 & 0.03 & 0.06 & -0.29 & 0.50 & 0.84 & -0.22 & & & & & & \\
\hline Eigenvalu & 6.74 & 5.13 & 3.83 & 2.61 & 2.50 & 1.59 & & 8.24 & 5.83 & 4.87 & 2.09 & 2.08 & 1.14 & 9.54 & 7.33 & 7.12 & 5.27 & 3.76 & 3.13 & 3.09 & 2.58 & 2.28 \\
\hline Variance & 24.54 & 19.17 & 15.71 & 11.03 & 8.48 & 7.95 & 7.06 & 27.10 & 22.56 & 15.30 & 14.74 & & 8.57 & 39.76 & 30.55 & 29.68 & 21.96 & 15.65 & 13.03 & 12.86 & 10.73 & 9.49 \\
\hline Cumulative & 24.54 & 43.71 & 59.41 & 70.44 & 78.92 & 86.87 & 93.93 & 27.10 & 49.67 & 64.96 & 79.70 & 88.43 & 97.01 & 39.76 & 70.32 & 100.00 & 21.96 & 37.61 & 50.65 & 63.50 & 74.23 & 83.72 \\
\hline
\end{tabular}


In Group B, six principal components (explaining 97.10\%) were kept. PC1 was highly related to $\mathrm{K}^{+}, \mathrm{Na}^{+}, \mathrm{Mg}^{2+}$, and $\mathrm{Li}$, while negative loading with Se; PC2 had high and positive loading with ORP and $\mathrm{Al}$, while negative loading with $\mathrm{EC}, \mathrm{Ca}$, and $\mathrm{Sr}$; PC3 was high and positively related to DO and $\mathrm{F}$, and negatively with $\mathrm{Ba} ; \mathrm{PC} 4, \mathrm{PC} 5$, and $\mathrm{PC} 6$ had high and positive loading with $\mathrm{NO}_{3}-\mathrm{N}, \mathrm{Cl}^{-}$, $\mathrm{SO}_{4}{ }^{2-}$, As, $\mathrm{pH}, \mathrm{T}$, and $\mathrm{NH}_{3}-\mathrm{N}$. In Group $\mathrm{C}$, three components totally explained the data. PC1 had high and positive loading with $\mathrm{pH}, \mathrm{T}$, and $\mathrm{DO}$, while negative loading with EC; PC2 was highly and negatively related to ORP, $\mathrm{NO}_{3}-\mathrm{N}$, and $\mathrm{Cl}^{-}$, and positively related to $\mathrm{NO}_{2}-\mathrm{N}, \mathrm{K}^{+}, \mathrm{Na}^{+}$, and Fe. $\mathrm{PC} 3$ had positive and high loading with $\mathrm{NO}_{3}-\mathrm{N}, \mathrm{Ca}^{2+}, \mathrm{As}$, and $\mathrm{Sr}$, negative loading with $\mathrm{NO}_{3}-\mathrm{N}, \mathrm{SO}_{4}{ }^{2-}$, and $\mathrm{Al}$. In Group D, six components (explaining $83.72 \%$ ) were ascertained. PC1 had positive and high loading with $\mathrm{K}^{+}, \mathrm{Na}^{+}, \mathrm{Mg}^{2+}, \mathrm{B}$, and As; $\mathrm{PC} 2$ was highly and positively related to $\mathrm{EC}, \mathrm{Ca}^{2+}$, and $\mathrm{Al}$, while it was negatively related to $\mathrm{pH}$; $\mathrm{PC} 3$ had positive and high loading with $\mathrm{SO}_{4}{ }^{2-}$ and $\mathrm{HCO}_{3}{ }^{-}$; $\mathrm{PC} 4, \mathrm{PC}$, and PC6 were highly and positively related to $\mathrm{DO}, \mathrm{ORP}, \mathrm{NH}_{3}-\mathrm{N}, \mathrm{NO}_{2}-\mathrm{N}$, and $\mathrm{NO}_{3}-\mathrm{N}$, while being negatively related to $\mathrm{Ba}$. The monitoring stations in Group B, Group C, and Group D all belonged to the river section replenished by reclaimed water, therefore, the high and negative loading with major cations and anions could be explained by the origin of treated wastewater (reclaimed water). Some parameters may be different among the three groups as a result of large spatial variability. The relation with ORP and nitrogen forms was different among different groups. Positive relation in Group B and Group D indicated that nitrification reaction was the controlling process of nitrogen forms. The $\mathrm{NH}_{3}-\mathrm{N}$, $\mathrm{NO}_{2}-\mathrm{N}$, and $\mathrm{NO}_{3}-\mathrm{N}$ in Group B were higher than the ones in Group $\mathrm{C}$ and Group D, which indicated that the degree of nitrification was greater $[42,43]$.

\subsection{Ionic Relationship and Hydro Geochemical Process}

\subsubsection{Gibbs Plot and Controlling Mechanism}

The mechanisms governing the water chemistry in surface water composition could be identified by the Gibbs plot [44]. Figure 9 presents the Gibbs plot of spatial clusters. No samples were found in evaporation crystallization and precipitation dominant zone, and all samples lied on the rock dominance zone. TDS of samples had smaller extent variation, while $\mathrm{Na}^{+} / \mathrm{Na}^{+}+\mathrm{Ca}^{2+}$ had bigger one. Group A with bigger variation of $\mathrm{Na}^{+} / \mathrm{Na}^{+}+\mathrm{Ca}^{2+}$ was located to the right, which showed low content of $\mathrm{Ca}^{2+}$. On the other hand, the river section recharged by reclaimed water-including Group B, Group $\mathrm{C}$, and Group D-had smaller variation and was located to the left. Most values of $\mathrm{Cl}^{-} / \mathrm{Cl}^{-}+\mathrm{HCO}_{3}{ }^{-}$ ranged from 0 to 0.5 , and samples were located to the left. Gibbs plot shows the controlling factors of surface water chemistry (river, ocean) which are not influenced by strong human activity [44]. The water in Group A was controlled by water-rock interaction, while the river water in other groups (Group B, Group C, and Group D) was governed by the water chemistry of reclaimed water. This result also could be confirmed by the higher concentration $(2.42 \mathrm{mg} / \mathrm{L})$ of $\mathrm{SiO}_{2}$ in Group A and lower value $(0.40-0.82 \mathrm{mg} / \mathrm{L})$ in other groups. 

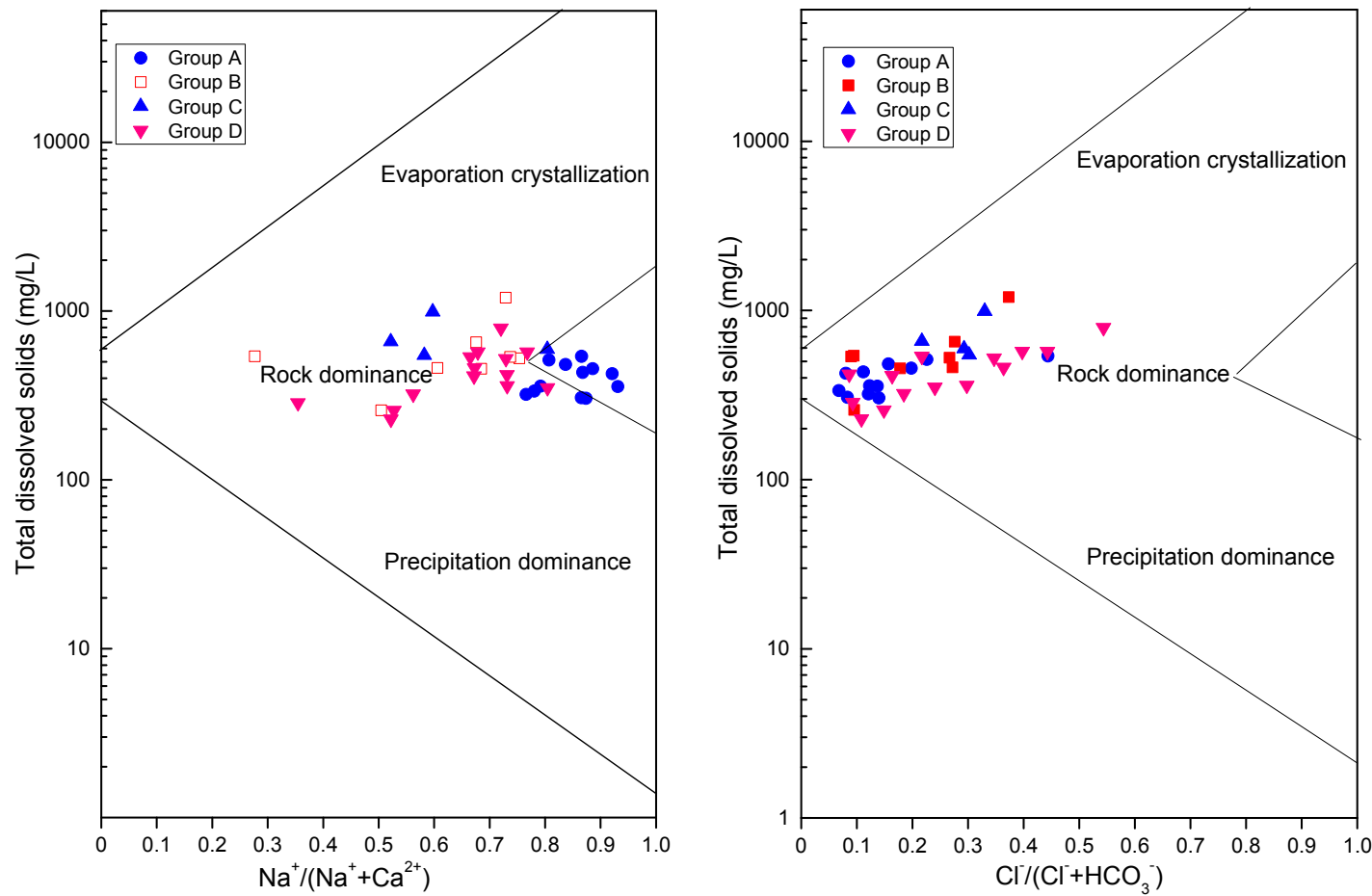

Figure 9. Gibbs plot of spatial clusters (Group A, Group B, Group C, and Group D) of monitoring stations.

\subsubsection{Bivariate Plot and Dissolution Reaction}

The ratio and bivariate relationship of different ions could be used to infer the mineral dissolution. Figure 10 shows the major ratio and relationship of samples in Yongding River. The $\mathrm{Ca}^{2+} / \mathrm{Mg}^{2+}$ (Figure 10a) of most samples was less than 1, which indicated the effects of dissolution of calcite and magnesium minerals, or cation exchange reaction causing calcium reduction; only one sample (YD05) has a value slightly greater than 2 ; the other samples were greater than 1 but less than 2 , indicating the dissolution of calcite [22]. The $\mathrm{Ca}^{2+}+\mathrm{Mg}^{2+}$ vs. Cation (Figure 10b) of samples were located above the equilibrium line, indicating that the dissolution of carbonate and calcite is the main source [24,25]. $\mathrm{Na}^{+}+\mathrm{K}^{+}$vs. $\mathrm{Cl}^{-}$(Figure 10c) of most waters were located below the equilibrium line, indicating that sodium and potassium ions were also affected by dissolution of salt rocks [45]. The $\mathrm{HCO}_{3}{ }^{-} \mathrm{vs}$. $\mathrm{Na}^{+}+\mathrm{Ca}^{2+}$ (Figure 10d) of most of the samples were located above the equilibrium line, indicating that sodium and calcium ions were much smaller than bicarbonate, confirming the dissolution of carbonate. Figure 10e shows that the natural water samples were mainly located above the equilibrium line, which showed the dissolution of carbonate, while the samples of the section replenished by reclaimed water were mainly located below the equilibrium line, indicating the effects of evaporation. The $\mathrm{Ca}^{2+}+\mathrm{Mg}^{2+}$ vs. $\mathrm{HCO}_{3}{ }^{-}+\mathrm{SO}_{4}{ }^{2-}$ (Figure 10f) of all water samples were located below the equilibrium line, indicating that the possible ion exchange between $\left(\mathrm{Na}^{+}, \mathrm{K}^{+}\right)$and $\left(\mathrm{Ca}^{2+}, \mathrm{Mg}^{2+}\right)$ or the precipitation of $\mathrm{Ca}^{2+}$ and $\mathrm{Mg}^{2+}[46,47]$. 

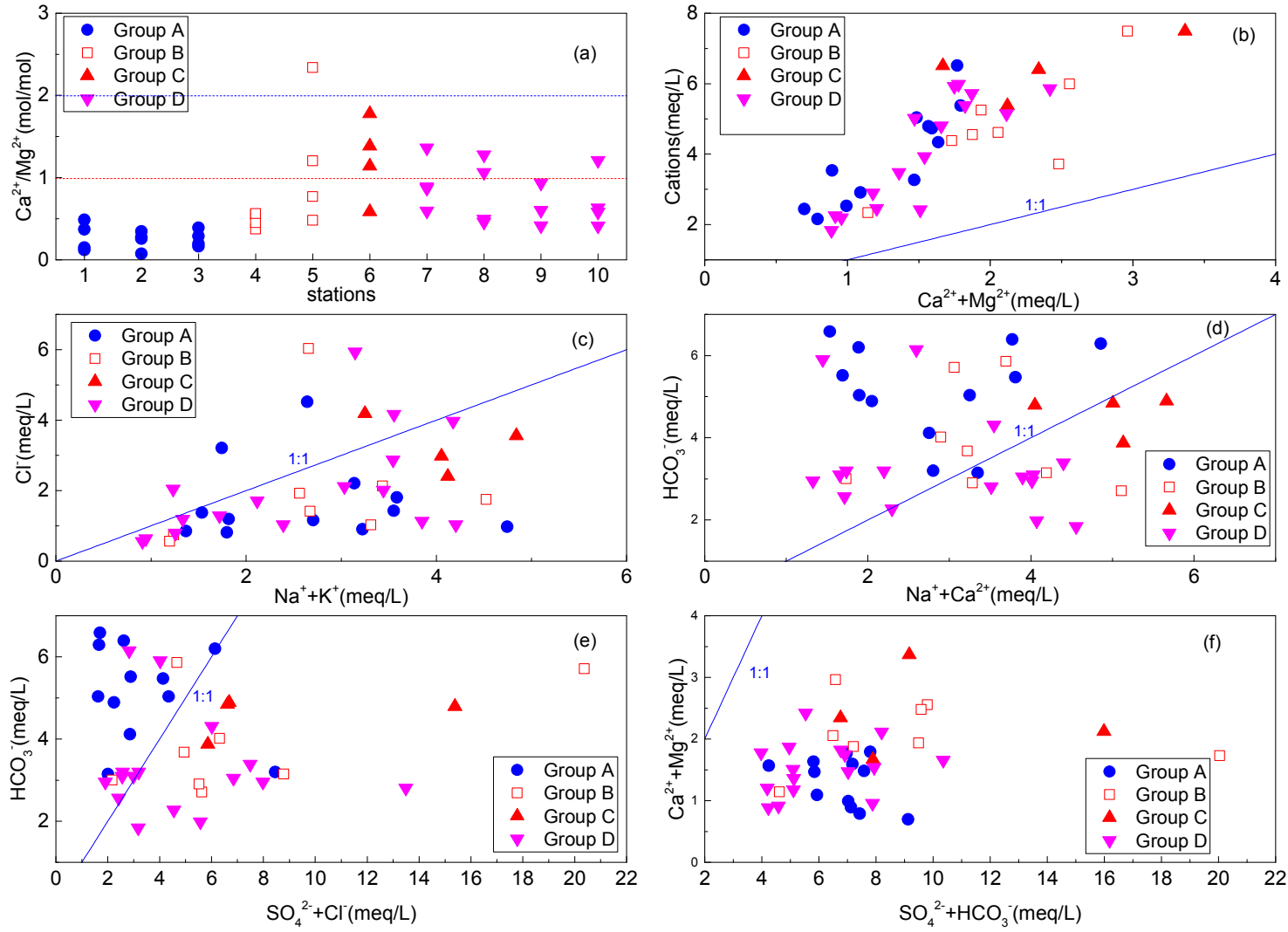

Figure 10. Plot of ratio of $\mathrm{Ca}^{2+} / \mathrm{Mg}^{2+}(\mathbf{a})$, bivariate plot of cation vs. $\mathrm{Ca}^{2+}+\mathrm{Mg}^{2+}(\mathbf{b}), \mathrm{Cl}^{-}$vs. $\mathrm{Na}^{+}+\mathrm{K}^{+}$ (c), $\mathrm{HCO}_{3}{ }^{-}$vs. $\mathrm{Na}^{+}+\mathrm{Ca}^{2+}\left(\right.$ d), $\mathrm{HCO}_{3}{ }^{-}$vs. $\mathrm{SO}_{4}{ }^{2-}+\mathrm{Cl}^{-}(\mathbf{e})$, and $\mathrm{Ca}^{2+} / \mathrm{Mg}^{2+}$ vs. $\mathrm{SO}_{4}{ }^{2-}+\mathrm{HCO}_{3}{ }^{-}$(f) in four groups.

The saturation of water samples in river water is given in Table 5. It is possible to determine the potential dissolution or precipitation process in the aqueous solution. The SI of gypsum $\left(\mathrm{CaSO}_{4}, \mathrm{CaSO}_{4} \cdot 2 \mathrm{H}_{2} \mathrm{O}\right)$ and halite $(\mathrm{NaCl})$ was negative, while the $\mathrm{SI}$ of calcite $\left(\mathrm{CaCO}_{3}\right)$ and dolomite $\left(\mathrm{CaMg}\left(\mathrm{CO}_{3}\right)_{2}\right)$ is positive. Positive SI value indicated that the mineral relative to the aqueous in a supersaturated state; a negative value indicated unsaturated state; a zero value indicated equilibrium state. This indicated the dissolution process of gypsum and salt rock, and the precipitation of calcite and dolomite may occur in both sections. The more $\mathrm{Na}^{+}$and $\mathrm{K}^{+}$in Figure 10c, and more $\mathrm{SO}_{4}{ }^{2-}$ in Figure 10f confirmed the potential dissolution process of gypsum and salt rock. Figure 10a,b,d showed the combination of carbonate and calcium and magnesium ions in the water, combined with saturated index of $\mathrm{CaCO}_{3}$ and $\mathrm{CaMg}\left(\mathrm{CO}_{3}\right)_{2}$, the precipitation process of carbonate could be further confirmed, which led to less $\mathrm{Ca}^{2+}$ and $\mathrm{Mg}^{2+}$ in Figure $10 \mathrm{f}$.

Table 5. Saturation index (SI) of samples in monitoring stations in Yongding River

\begin{tabular}{ccccccccccc}
\hline Rock & YD01 & YD02 & YD03 & YD04 & YD05 & YD06 & YD07 & YD08 & YD09 & YD10 \\
\hline $\mathrm{CaSO}_{4}$ & -3.09 & -2.49 & -2.87 & -2.07 & -2.31 & -1.79 & -2.21 & -2.62 & -2.43 & -2.49 \\
$\mathrm{CaCO}_{3}$ & 0.72 & 0.99 & 1.00 & 1.19 & 0.78 & 0.66 & 0.43 & 1.31 & 1.40 & 0.95 \\
$\left.\mathrm{CaMg}_{\mathrm{CO}}\right)_{2}$ & 1.62 & 2.30 & 2.16 & 2.42 & 1.23 & 0.80 & 0.47 & 2.40 & 2.67 & 1.64 \\
$\mathrm{CaSO}_{4} \cdot 2 \mathrm{H}_{2} \mathrm{O}$ & -2.84 & -2.24 & -2.62 & -1.82 & -2.05 & -1.53 & -1.96 & -2.36 & -2.18 & -2.24 \\
$\mathrm{NaCl}$ & -7.55 & -6.83 & -7.28 & -7.06 & -7.80 & -6.59 & -7.31 & -7.85 & -7.65 & -7.44 \\
\hline
\end{tabular}




\subsubsection{Nitrogen Forms and Redox Environment}

The availability of electrons for transfer between species was characterized by ORP, which could be measured in the field in surface water. The species of nitrogen in water were strongly affected by the redox environment [48,49]. In Figure 11, the ORP were mostly positive except for three samples, with positive values ranging from 47.4 to $214.6 \mathrm{mV}$, and the corresponding $\mathrm{DO}$ with variation from 7.21 to $18.0 \mathrm{mg} / \mathrm{L}$. Results showed oxic condition in most of the river water. The concentration of Fe was low in river water, with the average of $10.2 \mu \mathrm{g} / \mathrm{L}$. With the increase of ORP, the $\mathrm{NO}_{3}-\mathrm{N}$ of most samples changed little except five samples (one in Group D and four in Group A). The oxic environment was conducive to the stable form of $\mathrm{NO}_{3}-\mathrm{N}$, and did harm to denitrification [50]. As a result, the variation of $\mathrm{NO}_{3}-\mathrm{N}$ may be controlled by mixing/dilution and the absorption of aquatic plants.
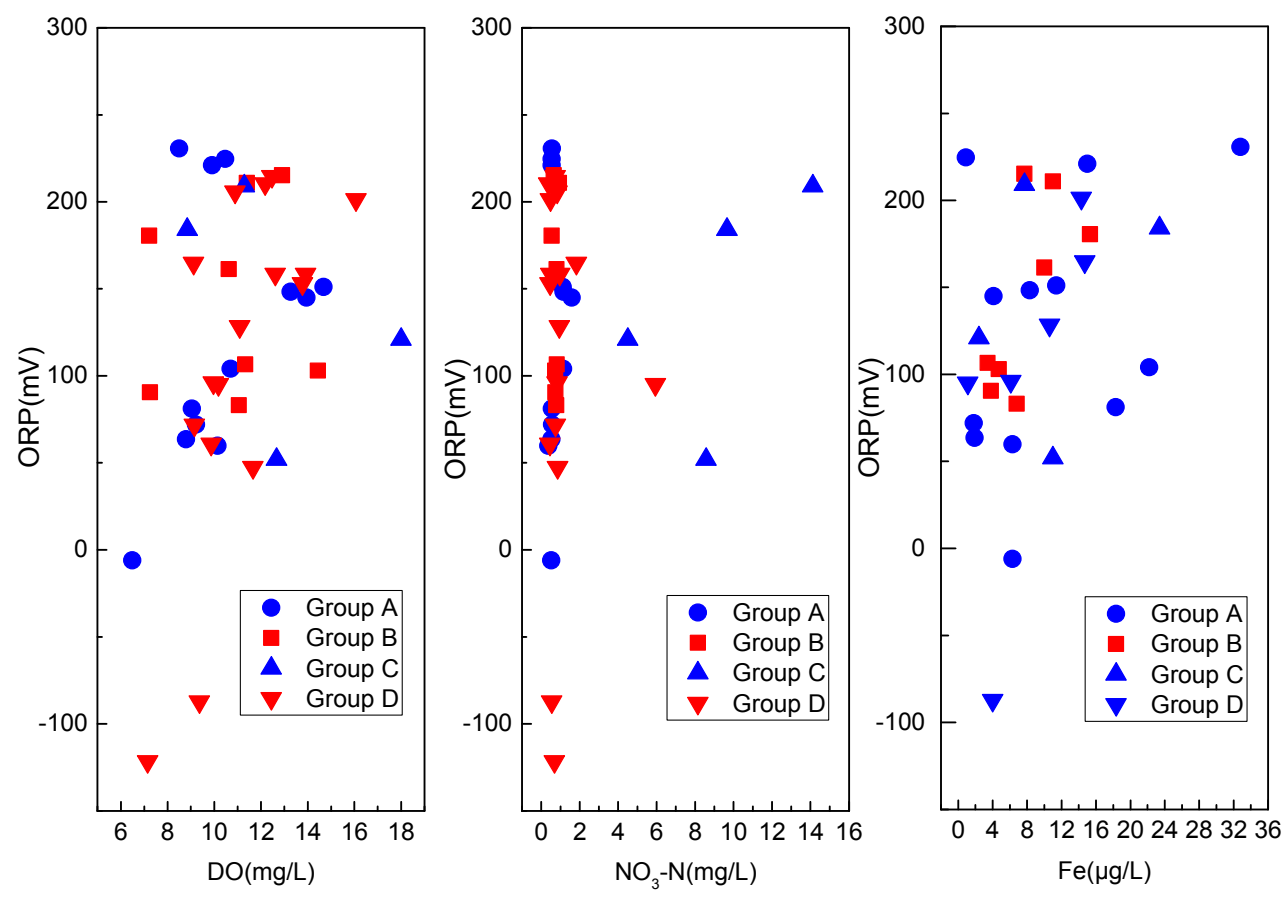

Figure 11. Relationship of ORP and major redox species (DO, $\mathrm{NO}_{3}-\mathrm{N}$ and $\mathrm{Fe}$ ) in Yongding River.

$\mathrm{pH}$ was another important factor affecting the fate of $\mathrm{NO}_{3}-\mathrm{N}$, and the $\mathrm{pH}-\mathrm{pE}$ (computed by Equation (1)) plot could evaluate the multiple influences of $\mathrm{pH}$ and ORP. The $\mathrm{pH}-\mathrm{pE}$ plot for spatial clusters was described in Figure 12. Most samples were located near the line $\left(\mathrm{NO}_{3}{ }^{-} / \mathrm{NO}_{2}{ }^{-}=1\right)$, where the stable nitrogen form was nitrate $\left(\mathrm{NO}_{3}{ }^{-},+5\right)$. This result strongly correlated to the oxic environment in the natural river section and the section recharged by reclaimed water, where the concentration of DO was more than $10 \mathrm{mg} / \mathrm{L}$. Several samples were found in the bottom part of diagram, where the stable nitrogen form was gaseous nitrogen $\left(\mathrm{N}_{2}, 0\right)$, which meant denitrification did not occur. 

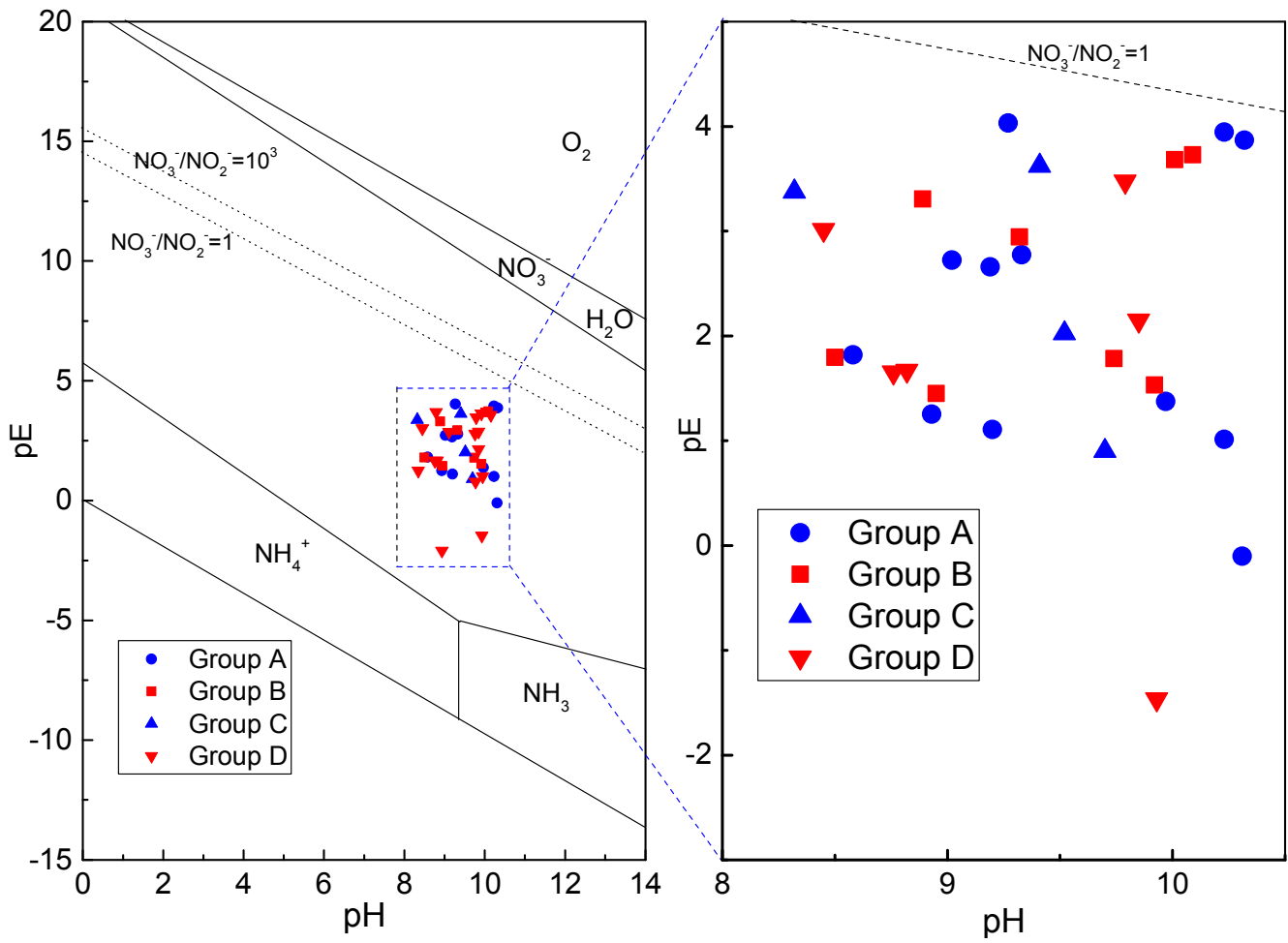

Figure 12. $\mathrm{pH}-\mathrm{pE}$ diagram of spatial clusters of samples in Yongding River.

\section{Conclusions}

This research focused on understanding the characteristics and major influencing factors of river water, and the major conclusions are as follows: all the waters are alkaline, and the $\mathrm{NO}_{3}-\mathrm{N}$ was the main nitrogen form, and the phosphorus of most samples is below detection level. The spatio-temporal variation was the occurrence of peak and valley of major water quality parameters, which was further confirmed by cluster analysis. Four seasons were divided into two groups both in the two river sections, and the same result of four seasons except winter belonging to one group was obtained. All the monitoring stations were classified into four groups. Based on the analysis of Gibbs plots, PCA, and ionic relationships, it is found that the rock dominance was the main controlling factor, which included dissolution of calcite, carbonate, salt rock, silicate, and poor magnesium minerals. The obvious variation of major cations could be explained by the cation exchange reaction. The oxidation environment in most river water was conducive to the stable form of $\mathrm{NO}_{3}-\mathrm{N}$, and did harm to denitrification. Nitrogen content of reclaimed water should be further reduced before discharge in order to avoid the eutrophication in river water.

Acknowledgments: This research was financially supported by the National Natural Science Foundation of China (NO. 41601037). We wish to thank the three anonymous reviewers for their invaluable comments and constructive suggestions used to improve the quality of the manuscript.

Author Contributions: Yilei Yu had the original idea for the study, and carried out the design with all co-authors. Yilei Yu drafted the manuscript, which was revised by all authors. Licai Liu, Yongmin Yang, Nana Zhao, and Xiaoxia Li had collected the samples in field and analyzed the water chemistry in the laboratory. Muyuan Ma, Jia Guo, and Fandong Zheng performed the data analysis. All authors read and approved the final manuscript.

Conflicts of Interest: The authors declare no conflicts of interest.

\section{References}

1. Jun, X. Water cycle and water resources security in North China: Problems and challenges. Adv. Geogr. 2002, $21,517-526$. 
2. Zhou, Z.; Li, M.; Liu, W.; Jiao, Z.; Sun, F. Beijing Water Resoureces Bulletin; B.W. Authority: Beijing, China, 2015.

3. Sun, Y.; Chen, Z.; Wu, G.; Wu, Q.; Zhang, F.; Niu, Z.; Hu, H.-Y. Characteristics of water quality of municipal wastewater treatment plants in China: Implications for resources utilization and management. J. Clean. Prod. 2016, 131, 1-9. [CrossRef]

4. Yang, H.; Abbaspour, K.C. Analysis of wastewater reuse potential in Beijing. Desalination 2007, 212, $238-250$. [CrossRef]

5. Wang, Z.; Li, J.; Li, Y. Using reclaimed water for agricultural and landscape irrigation in China: A review. Irrig. Drain. 2017. [CrossRef]

6. Furumai, H. Rainwater and reclaimed wastewater for sustainable urban water use. Phys. Chem. Earth Parts A/B/C 2008, 33, 340-346. [CrossRef]

7. Li, H.; Gong, X.; Gu, B.; Li, J.; Zhu, X. Study on water quality control measures of reclaimed water used in Yongding River landscape water. Beijing Water Aff. 2012, 3, 41-43. (In Chinese).

8. Qin, C.; Liu, H.; Liu, L.; Smith, S.; Sedlak, D.L.; Gu, A.Z. Bioavailability and characterization of dissolved organic nitrogen and dissolved organic phosphorus in wastewater effluents. Sci. Total Environ. 2015, 511, 47-53. [CrossRef] [PubMed]

9. Xiong, J.; Wang, X.C.; Zhang, Q.; Duan, R.; Wang, N. Characteristics of a landscape water with high salinity in a coastal city of China and measures for eutrophication control. Ecol. Indic. 2016, 61, 268-273. [CrossRef]

10. Paerl, H.W.; Gardner, W.S.; McCarthy, M.J.; Peierls, B.L.; Wilhelm, S.W. Algal blooms: Noteworthy nitrogen. Science 2014, 346, 175. [CrossRef] [PubMed]

11. Asano, T. Artificial Recharge of Groundwater; Elsevier: Boston, MA, USA, 2016.

12. Chen, W.; Lu, S.; Jiao, W.; Wang, M.; Chang, A.C. Reclaimed water: A safe irrigation water source? Environ. Dev. 2013, 8, 74-83. [CrossRef]

13. Qiu, Y.; Wang, H.; Li, S.; Ma, J.; Peng, Y.; Li, F. Study on effects of reclaimed water irrigation on the soil and shallow groundwater salinity. J. Tarim Univ. 2016, 28, 72-79. (In Chinese).

14. Duan, W.; Takara, K.; He, B.; Luo, P.; Nover, D.; Yamashiki, Y. Spatial and temporal trends in estimates of nutrient and suspended sediment loads in the Ishikari River, Japan, 1985 to 2010. Sci. Total Environ. 2013, 461-462, 499-508. [CrossRef] [PubMed]

15. Hao, R.X.; Li, S.M.; Li, J.B.; Zhang, Q.K.; Liu, F. Water quality assessment for wastewater reclamation using principal component analysis. J. Environ. Inf. 2013, 21, 45-54. [CrossRef]

16. Subba, R.N.; Prakasa, R.J.; John, D.D.; Srinivasa, R.K.; Krishna, C. Multivariate analysis for identifying the governing factors of groundwater quality. J. Environ. Hydrol. 2001, 9, 1-9.

17. Haag, I.; Westrich, B. Processes governing river water quality identified by principal component analysis. Hydrol. Process. 2002, 16, 3113-3130. [CrossRef]

18. Petersen, W.; Bertino, L.; Callies, U.; Zorita, E. Process identification by principal component analysis of river water-quality data. Ecol. Model. 2001, 138, 193-213. [CrossRef]

19. Duan, W.; He, B.; Nover, D.; Yang, G.; Chen, W.; Meng, H.; Zou, S.; Liu, C. Water Quality Assessment and Pollution Source Identification of the Eastern Poyang Lake Basin Using Multivariate Statistical Methods. Sustainability 2016, 8, 133. [CrossRef]

20. Costa, M.; Gonçalves, A.M. Clustering and forecasting of dissolved oxygen concentration on a river basin. Stoch. Environ. Res. Risk Assess. 2010, 25, 151-163. [CrossRef]

21. Oketola, A.A.; Adekolurejo, S.M.; Osibanjo, O. Water quality assessment of River Ogun using multivariate statistical techniques. J. Environ. Prot. 2013, 4, 466-479. [CrossRef]

22. Smolders, A.J.P.; Hudson-Edwards, K.A.; Velde, G.V.D.; Roelofs, J.G.M. Controls on water chemistry of the Pilcomayo river (Bolivia, South-America). Appl. Geochem. 2004, 19, 1745-1758. [CrossRef]

23. Stallard, R.F.; Edmond, J.M. Geochemistry of the Amazon: 2. The influence of geology and weathering environment on the dissolved load. J. Geophys. Res. 1983, 88, 9671-9688. [CrossRef]

24. Liu, B.; Liu, C.Q.; Zhang, G.; Zhao, Z.Q.; Li, S.L.; Hu, J.; Ding, H.; Lang, Y.C.; Li, X.D. Chemical weathering under mid-to cool temperate and monsoon-controlled climate: A study on water geochemistry of the Songhuajiang River system, northeast China. Appl. Geochem. 2013, 31, 265-278. [CrossRef]

25. Zhu, B.; Yu, J.; Qin, X.; Rioual, P.; Zhang, Y.; Liu, Z.; Yan, M.; Li, H.; Ren, X.; Xiong, H. Identification of rock weathering and environmental control in arid catchments (northern Xinjiang) of Central Asia. J. Asian Earth Sci. 2013, 66, 277-294. [CrossRef] 
26. Jiang, B.; Wong, C.P.; Lu, F.; Ouyang, Z.; Wang, Y. Drivers of drying on the Yongding River in Beijing. J. Hydrol. 2014, 519, 69-79. [CrossRef]

27. Liang, S.; Fan, H.; Wang, L.; Yang, J.; Gao, J.; Feng, M. Study on suitability observation of ecological revetment model of Yongding River. Soil Water Conserv. Res. 2012, 19, 153-158.

28. Mujica, L.E.; Vehí, J.; Ruiz, M.; Verleysen, M.; Staszewski, W.; Worden, K. Multivariate statistics process control for dimensionality reduction in structural assessment. Mech. Syst. Signal Process. 2008, 22, 155-171. [CrossRef]

29. Reimann, C.; Filzmoser, P. Normal and lognormal data distribution in geochemistry death of a myth. Consequences for the statistical treatment of geochemical and environmental data. Environ. Geol. 2000, 39, 1001-1014. [CrossRef]

30. Cao, Y.; Tang, C.; Song, X.; Liu, C.; Zhang, Y. Characteristics of nitrate in major rivers and aquifers of the Sanjiang Plain, China. J. Environ. Monit. 2012, 14, 2624-2633. [CrossRef] [PubMed]

31. Surface Water Environmental Quality Standard (gb3838-2002); China Environmental Science Press: Beijing, China, 2002.

32. Chen, L.; Yang, K.; Song, X.; He, Y.; Fan, J. Urban Wastewater Recycling Landscape Water Quality (GB/T 18921-2002); General Administration of Quality Supervision, Inspection and Quarantine of the People 's Republic of China: Beijing, China, 2002.

33. Truesdale, G.; Downing, A.; Lowden, G. The solubility of oxygen in pure water and sea-water. J. Chem. Technol. Biotechnol. 1955, 5, 53-62. [CrossRef]

34. Tromans, D. Temperature and pressure dependent solubility of oxygen in water: A thermodynamic analysis. Hydrometallurgy 1998, 48, 327-342. [CrossRef]

35. Zhou, W.; Yuan, X.; Long, A.; Huang, H.; Yue, W. Different hydrodynamic processes regulated on water quality (nutrients, dissolved oxygen, and phytoplankton biomass) in three contrasting waters of Hong Kong. Environ. Monit. Assess. 2014, 186, 1705-1718. [CrossRef] [PubMed]

36. Radwan, M.; Willems, P.; El-Sadek, A.; Berlamont, J. Modelling of dissolved oxygen and biochemical oxygen demand in river water using a detailed and a simplified model. Int. J. River Basin Manag. 2003, 1, 97-103. [CrossRef]

37. Gelda, R.K.; Effler, S.W. A river water quality model for chlorophyll and dissolved oxygen that accommodates zebra mussel metabolism. Water Qual. Ecosyst. Model. 2000, 1, 271-309. [CrossRef]

38. Abowei, J.F.N. Salinity, dissolved oxygen, $\mathrm{pH}$ and surface water temperature conditions in Nkoro River, Niger Delta, Nigeria. Adv. J. Food Sci. Technol. 2010, 2, 67-71.

39. Kaiser, H.F. The varimax criteria for analytical rotation in factor analysis. Psychometrika 1958, 23, $187-200$. [CrossRef]

40. Mazlum, N.; Ozer, A.; Mazlum, S.U. Interpretation of water quality data by principal components analysis. J. Eng. Environ. Sci. 1999, 23, 19-26.

41. Kim, J.-H.; Kim, R.-H.; Lee, J.; Cheong, T.-J.; Yum, B.-W.; Chang, H.-W. Multivariate statistical analysis to identify the major factors governing groundwater quality in the coastal area of Kimje, South Korea. Hydrol. Process. 2005, 19, 1261-1276. [CrossRef]

42. Strauss, E.A.; Richardson, W.B.; Bartsch, L.A.; Cavanaugh, J.C.; Bruesewitz, D.A.; Imker, H.; Heinz, J.A.; Soballe, D.M. Nitrification in the Upper Mississippi River: Patterns, controls, and contribution to the $\mathrm{NO}_{3}{ }^{-}$ budget. J. N. Am. Benthol. Soc. 2004, 61, 1102-1112. [CrossRef]

43. Zhao, L.; Delatolla, R.; Mohammadian, A. Nitrification kinetics \& modified model for the Rideau River, Canada. Water Qual. Res. J. Can. 2013, 48, 192-201.

44. Gibbs, R.J. Mechanisms controlling world water chemistry. Science 1970, 170, 1088-1090. [CrossRef] [PubMed]

45. Moon, S.; Huh, Y.; Qin, J.; Pho, N.V. Chemical weathering in the Hong (Red) River basin: Rates of silicate weathering and their controlling factors. Geochim. Cosmochim. Acta 2007, 71, 1411-1430. [CrossRef]

46. Fan, B.L.; Zhao, Z.Q.; Tao, F.X.; Liu, B.J.; Tao, Z.H.; Gao, S.; Zhang, L.H. Characteristics of carbonate, evaporite and silicate weathering in huanghe river basin: A comparison among the upstream, midstream and downstream. J. Asian Earth Sci. 2014, 96, 17-26. [CrossRef]

47. Li, J.; Yuan, G.L.; Deng, X.R.; Jing, X.M.; Sun, T.H.; Lang, X.X.; Wang, G.H. Major ion geochemistry of the Nansihu Lake basin rivers, North China: Chemical weathering and anthropogenic load under intensive industrialization. Environ. Earth Sci. 2016, 75, 453. [CrossRef] 
48. Yan, W.; Yang, L.; Wang, F.; Wang, J.; Ma, P. Riverine N2O concentrations, exports to estuary and emissions to atmosphere from the Changjiang River in response to increasing nitrogen loads. Glob. Biogeochem. Cycles 2012, 26. [CrossRef]

49. Jahangir, M.M.R.; Khalil, M.I.; Johnston, P.; Cardenas, L.M.; Hatch, D.J.; Butler, M.; Barrett, M.; O'flaherty, V.; Richards, K.G. Denitrification potential in subsoils: A mechanism to reduce nitrate leaching to groundwater. Agric. Ecosyst. Environ. 2012, 147, 13-23. [CrossRef]

50. Gomez-Velez, J.D.; Harvey, J.W.; Cardenas, M.B.; Kiel, B. Denitrification in the Mississippi River network controlled by flow through river bedforms. Nat. Geosci. 2015, 8, 941-945. [CrossRef] 